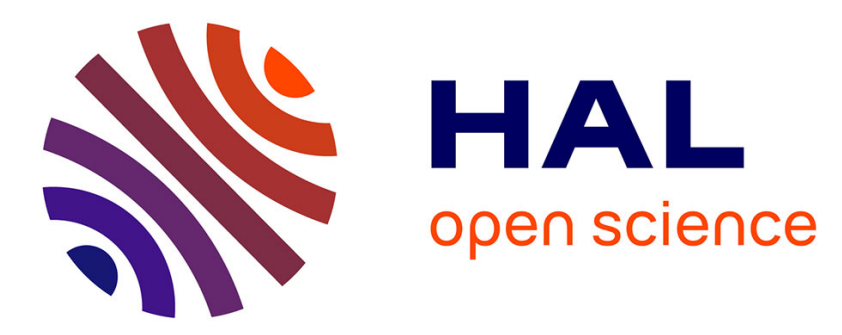

\title{
Overview of Protein-Based Biopolymers for Biomedical Application
}

\author{
Sakthivel Nagarajan, Socrates Radhakrishnan, S. Narayana Kalkura, \\ Sébastien Balme, Philippe Miele, Mikhael Bechelany
}

\section{- To cite this version:}

Sakthivel Nagarajan, Socrates Radhakrishnan, S. Narayana Kalkura, Sébastien Balme, Philippe Miele, et al.. Overview of Protein-Based Biopolymers for Biomedical Application. Macromolecular Chemistry and Physics, 2019, 220 (14), pp.1900126. 10.1002/macp.201900126 . hal-02270644

\section{HAL Id: hal-02270644 \\ https://hal.umontpellier.fr/hal-02270644}

Submitted on 31 May 2021

HAL is a multi-disciplinary open access archive for the deposit and dissemination of scientific research documents, whether they are published or not. The documents may come from teaching and research institutions in France or abroad, or from public or private research centers.
L'archive ouverte pluridisciplinaire HAL, est destinée au dépôt et à la diffusion de documents scientifiques de niveau recherche, publiés ou non, émanant des établissements d'enseignement et de recherche français ou étrangers, des laboratoires publics ou privés. 


\title{
Overview of protein based biopolymers for biomedical application
}

\section{Sakthivel Nagarajan ${ }^{a}$, Socrates Radhakrishnan ${ }^{\mathrm{c}}$, S. Narayana Kalkura ${ }^{\mathrm{c}}$, Sebastien Balme ${ }^{\mathrm{a}}$, Philippe Miele ${ }^{\mathrm{a}, \mathrm{b}^{*}}$, Mikhael Bechelany ${ }^{\mathrm{a}^{*}}$}

a- Institut Européen des Membranes, IEM - UMR 5635, ENSCM, CNRS, Univ Montpellier, Montpellier, France

b- Institut Universitaire de France (IUF), MESRI, 1 rue Descartes, 75231 Paris cedex 05, France c- Crystal Growth Centre, Anna University, Chennai. 600025 India

Corresponding authors: Philippe.Miele@ umontpellier.fr and mikhael.bechelany@ umontpellier.fr

\begin{abstract}
Biopolymers are playing a vital role in biomedical applications. Among them, protein based biopolymers are utilized for the fabrication of tissue engineering constructs, therapeutic molecule delivery carriers, emulsifiers and food packaging materials. Wide ranges of proteins are extracted from animal or plant sources and are being utilized for the fabrication of scaffolds for regenerative tissue engineering application. Here, an overview about the protein structure, extraction procedure, solubility and various formulation based proteins used in the literature are discussed. Biopolymers display several advantageous such as biocompatibility and degradability by enzymes. Methods to overcome the disadvantages of these proteins such as immunogenicity, antigenicity and solubility will be reported. Various crosslinking reagents specific to protein chemistry will be as well discussed.
\end{abstract}

TOC

Protein based biopolymers are one of the promising class of biomaterials due to their biocompatibility and biodegradability. In this review, protein based biopolymers derived from animals and plants are elaborately discussed. Chemical structures of biopolymer and crosslinking based stabilization of biopolymer are also provided. Different formulations fabricated using 
protein based biopolymers and their importance in tissue engineering and therapeutic molecule delivery are also covered in this report.

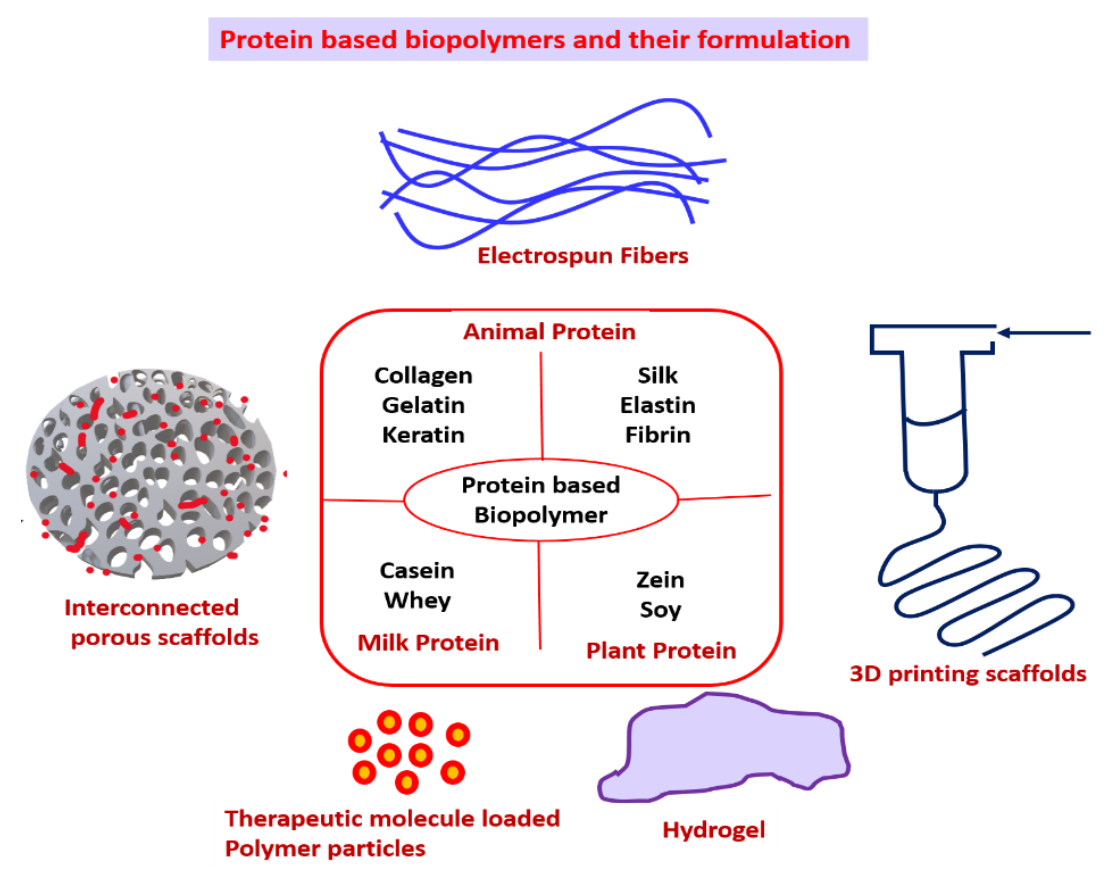

\section{Biographies}

\section{Sakthivel Nagarajan}

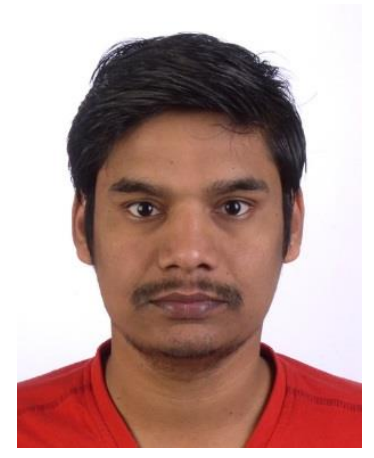

Dr Sakthivel Nagarajan is currently working as a post-doctoral researcher at Institute of European Membranes (IEM), University of Montpellier, Montpellier, France. He had completed his PhD at Crystal Growth Centre, Anna University, Chennai, India on 2017. During the PhD, he spent two years (2014-2016) as a visiting student in IEM. His current research aims to design biopolymer based scaffolds using electrospinning, 3D printing and surface modification of biopolymer scaffolds for tissue engineering and drug delivery application.

\section{Philippe Miele}




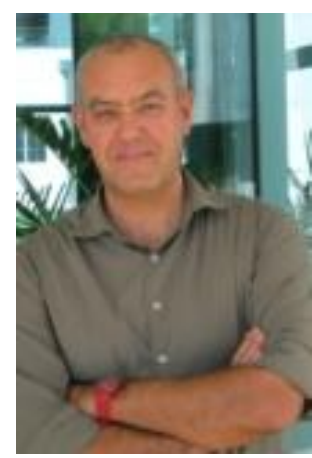

Prof. Dr. Philippe Miele received his PhD in Inorganic Chemistry in 1993 from the University of Montpellier. Following a postdoctoral fellowship at Georgia Institute of Technology (Atlanta, GA, USA), he became Assistant Professor (1994), and then Professor at the University Lyon 1. He was the leader of the group "Molecular Precursors and Inorganic Materials" in the Laboratory of Multimaterials and Interfaces (UMR UCBL / CNRS 5615). In 2003, he was appointed to the position of Lab Head up to 2010. In fall 2010, he joined the European Institute of Membranes of Montpellier (UMR CNRS 5635) with a part of his former group setting up the "Molecular Materials and Ceramics" group. In 2011, he has been appointed to his present position as Lab Head. Its main research interests lie in boron chemistry and in non-oxide advanced ceramics using the Polymer Derived Ceramics route, particularly new boron- and silicon-based materials. He was nominated junior member of the "Institut Universitaire de France" in 2003, and in 2011 has been appointed in "World Academy of Ceramics" as Professional Member (Academician) and is affiliated with the class "Science".

\section{Mikhael Bechelany}

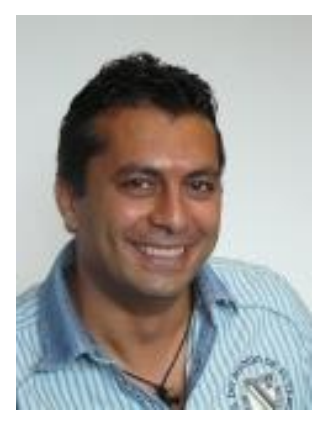

Dr. Mikhael Bechelany obtained his PhD in Materials Chemistry from the University of Lyon (France) in 2006. His PhD work was devoted to the synthesis and characterization of silicon and boron based 1D nanostructures (nanotubes, nanowires and nanocables). Then, he worked as a post-doc at EMPA (Switzerland). His research included the fabrication of nanomaterials (nanoparticles and nanowires), their organization and their nanomanipulation for applications in different field such as photovoltaic, robotic, chemical and bio-sensing. In 2010, he became a Scientist at CNRS. His current research interest in the European Institute of Membranes of Montpellier (UMR CNRS 5635) in Montpellier (France) focuses on novel synthesis methods for metals and ceramics nanomaterials like Atomic Layer Deposition (ALD), electrodeposition, electrospinning and/or on the nanostructuring using natural lithography (nanospheres and/or membranes). His research efforts include the design of nanostructured membranes for health, environment and renewable energy. 


\section{Introduction}

Biopolymers are polymeric compounds found in living organisms such as animals, plants, bacteria and algae ${ }^{[1]}$. They are widely divided as polysaccharide, polypeptides and polynucleotides, based on their monomeric unit ${ }^{[1,2]}$. They are usually extracted from the living system or wastes through various chemical processes ${ }^{[3]}$. The processing conditions significantly affect their physiochemical properties including the hierarchical assembly. Hierarchical assembly of biopolymers imparts excellent properties such as high mechanical properties and superhydrophobicity ${ }^{[4]}$. However, fabricating materials mimicking hierarchical assembly using the extracted biopolymer is arduous. Indeed extracted biopolymers are employed for various applications such as tissue engineering, therapeutic molecule delivery and food packaging applications ${ }^{[5]}$. Regenerative tissue engineering aims to ameliorate the function of damaged tissues or malfunctioning organs using bodies own healing capacity. Synthetic and bio-polymers are employed as scaffolds for the cells to create a conducive niche that can facilitate cell proliferation and healing of damaged tissue. Among the various classes of materials, biopolymers are interesting due to their biocompatibility, the presence of biomimetic chemical entities, their biodegradability, their low toxicity and the release of nontoxic fragments during degradation ${ }^{[6]}$. Hence, biopolymers are widely utilized for the fabrication of tissue engineering constructs and drug delivery formulations.

Proteins such as collagen, gelatin, keratin, sericin and fibroin are employed for the fabrication of various formulations such as films, pickering emulsion, hydrogel, nanogel,

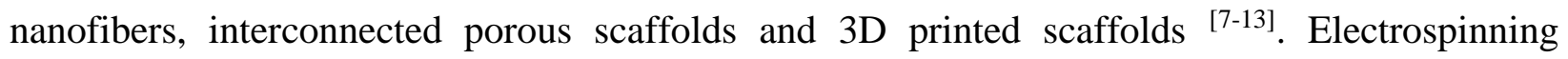
technique is found to be promising methods for the fabrication of scaffolds in tissue engineering applications ${ }^{[14]}$. These formulations were considered for the regeneration of hard and soft tissues such as wound, bone, cartilage and nerve tissues. Apart from animal derived proteins, plant derived proteins such as soy protein and zein are also widely studied for biomedical applications as discussed in this review. In general, extracted biopolymers display poor mechanical properties (toughness and elasticity) and poor film forming tendency and they are or highly brittle. Hence, physical properties of the biopolymer scaffolds can be improved by reinforcing with synthetic polymers and inorganic nanoparticles ${ }^{[8]}$. Despite that the biopolymers display several advantages, properties such as antigenicity and immunogenicity limit their applications. These 
disadvantages can be resolved or minimized by carefully optimizing the extraction procedure to eliminate the antigenic residues.

Several recent reviews deal with protein based polymers. Nitta et al. and Elzoghby et al. reported various protein based biopolymers for the drug delivery and tissue engineering applications. Ni et al. described the importance of protein based hydrogel formulation for biomedical application ${ }^{[2,5,15,16]}$. This review provides the new trend in the field of polypeptides and their formulations currently employed for the fabrication of tissue engineering scaffolds and drug delivery carriers. This review focused also on the new interesting research areas that have not been reviewed before such as electrospinning, 3D printing and bioink fabrication using biopolymers. It is formatted in order to briefly discuss the structure of individual protein, the solubility, the crosslinking chemistry, the degradability with enzymes, the approved products formulations in the market and the selected literatures to substantiate the suitability of the material for tissue engineering and drug delivery applications.

\section{Collagen}

Collagen is one of the highly abundant proteins in human system. 29 types of collagen have been discovered. Distribution of various types of collagen has been reported by Shoulders

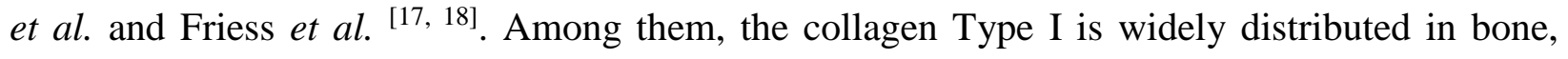
tendon and skin. It is mainly employed as biomaterial for the fabrication of drug delivery system and tissue engineering constructs. Collagen type I triple helix possesses three polypeptides chains which contain repeating units of Gly (glycine)-X-Y. The ' $\mathrm{X}$ ' and ' $\mathrm{Y}$ ' positions are mainly occupied by proline and 4-hydroxyproline. Glycine contains short side chains which found advantageous in order to facilitate the close package of the polypeptide chain in triple helix. Collagen type I fibrils observed in tendons are up to $\sim 500 \mathrm{~nm}$ diameter. Individual triple helix collagen molecule is known as tropocollagen which are $<2 \mathrm{~nm}$ in diameter, $\sim 300 \mathrm{~nm}$ long and flanked by non-triple helical telopeptide as shown in Figure 1a. Collagen molecule contains three left handed polypeptide chains which are intertwined into right handed triple helix. Tropocollagen is unstable in physiological temperature, their self-assembly leads to micro fibrils and further nucleated into macroscopic fibrous network as observed in tissues ${ }^{[18]}$. 
Collagen Type I, II, III, V and XI are fibril forming in nature ${ }^{[19]}$. Three dimensional assemblies of collagen fibrils provide a mechanical and structural support to the extracellular matrix in animals. Collagen based materials are advantageous in biomaterial fabrication for tissue engineering. It is due to the enhanced cell-material interaction of collagen scaffolds after implantation, which is necessary for cell attachment and proliferation. Enhanced cell adhesion on collagen scaffold can be explained as follows: (i) cell receptors such as glycoprotein VI (bind with (Gly-Pro-Hyp) sequence of collagen) and (ii) integrin family and discoidin domain receptor 1 and 2 selectively recognize peptide sequences of collagen and facilitate the cell adhesion ${ }^{[20]}$. We can note also that extracted collagen can be reconstituted into microfibrills which are similar to fibrous nature of the extracellular matrix (ECM). Crosslinked collagen scaffolds display enhanced tensile strength (92.5 MPa) suitable for high load bearing applications ${ }^{\text {[21, 22] }}$. Collagen extracted from bovine, porcine, fish, marine sponges and jelly fish are mainly studied to employ as a biomaterials. Chemical treatment of collagen during the extraction destroys the natural crosslinking ${ }^{[17]}$. Collagen based biomaterials are degradable by collagenase enzyme. Hence biomaterials fabricated using the collagen requires inter and intra molecular crosslinking in order to improve the mechanical properties. In general, crosslinkers such as glutaraldehyde, N-hydroxy succinimide, carbodiimide, formaldehyde, hexamethylenediisocyanate, sodium tripolyphosphate, genipin transglutaminase and sugar based crosslinkers were employed to ameliorate the stability of the collagen scaffolds, especially to avoid the rapid enzymatic degradation ${ }^{[23-28]}$. Dialdehyde obtained through the periodate oxidation of polysaccharide were also widely utilized for crosslinking collagen ${ }^{[29]}$. Immunogenicity and heterogeneity limit the application of collagen in biomaterial fabrication. However, crosslinking the collagen and atelocollagen (removing the nonhelical collagen molecules using pepsin treatment) found to decrease significantly the antigenicity and immunogenicity of collagen ${ }^{[30]}$. 


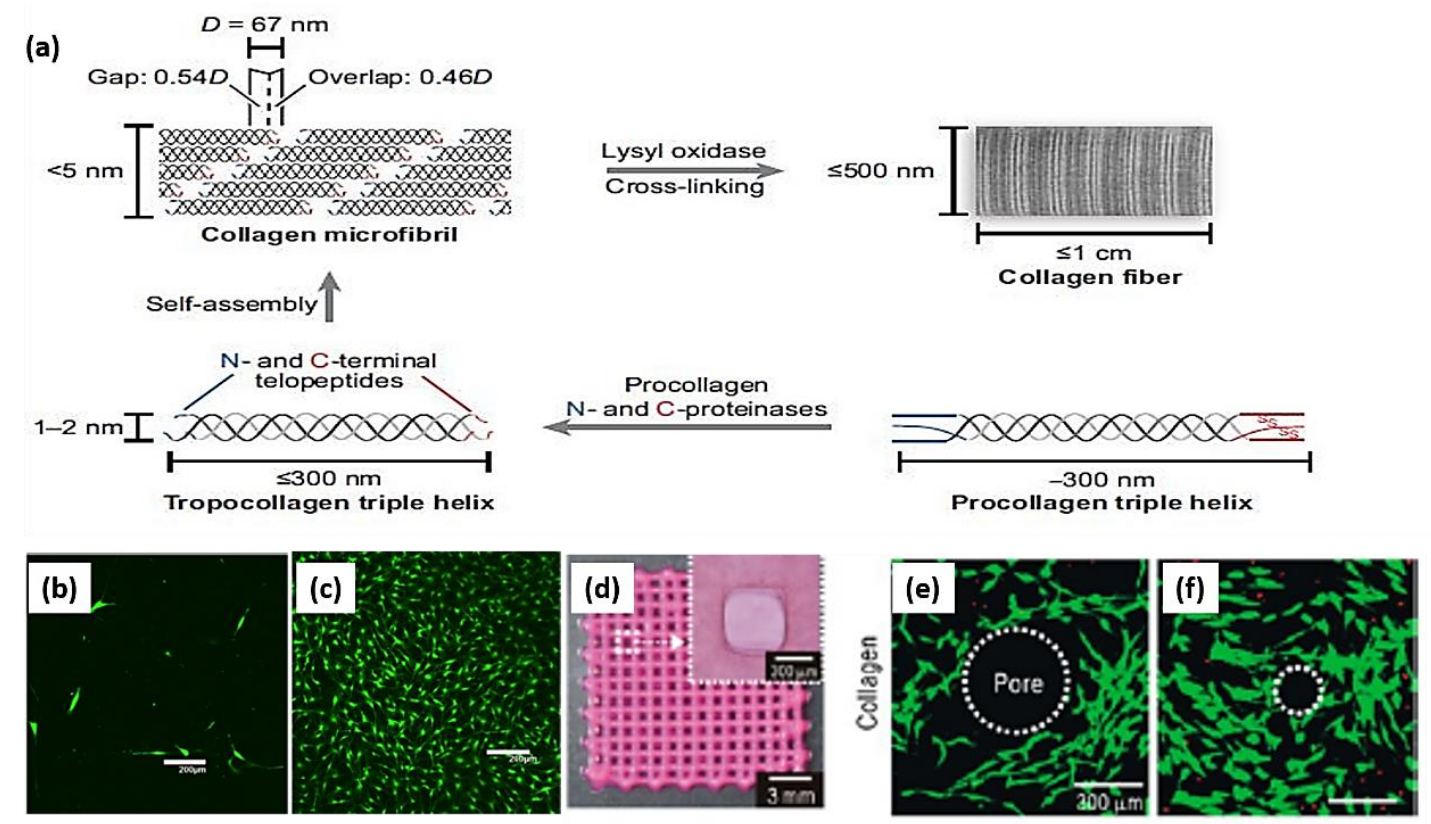

Figure 1. (a) Hierarchical assembly of collagen. (b) proliferation of lung fibroblast on collagen hydrogel for 1 day, (c) 8 days, (d) Bioprinted collagen scaffolds, proliferation of MG63 cells on 3D printed scaffolds for (e) 1day and (f) 7 days ${ }^{[18,31,32]}$.

Collagen based nanoparticles, nanospheres, electrospun fibers sponges and hydrogel are used for tissue engineering and therapeutic molecules (drug delivery, gene delivery, protein delivery) delivery application ${ }^{[17,33]}$. Collagen displays thrombogenic properties by activating the polymerization of fibrinogen into fibrin. The fibrin controls the clotting of blood ${ }^{[21]}$. Such properties are utilized and several collagen based formulations are currently available in the market (Gentamicin implant - Innocoll, Zbigniew, VITAGEL ${ }^{\mathrm{TM}}$, Avitene ${ }^{\mathrm{TM}}$ Helistat $^{\circledR}$, FloSeal ${ }^{\circledR}$ Alloderm $\AA$, Promogran $\AA$, Biobrane $\AA$, OrCel ${ }^{\circledR}$ and Ultrafoam ${ }^{\mathrm{TM}}$ ). Scaffolds and payload delivery carriers fabricated using collagen has been successfully demonstrated for the delivery of growth factors (GF) and drugs. Therapeutic molecules are immobilized through covalent or noncovalent immobilization. GF are mainly peptides which modulates the proliferation, differentiation and migration of cells ${ }^{[34]}$. Quinlan et al. fabricated bone morphogenetic protein (BMP) loaded microparticles and incorporated into collagen scaffolds. BMP incorporated scaffolds display sustained release of BMP (in vitro). The in vivo results delineate that the scaffolds are promising material for the bone regeneration and therapeutic molecule delivery ${ }^{[35]}$. 
Furthermore, collagen scaffolds were successfully demonstrated for loading various other growth factors such as human bone morphogenetic protein 2, neural growth factors and pro-angiogenic FGF-2 which facilitate the cell proliferation and differentiation. $\mathrm{n}^{[36-38]}$.In order to facilitate the bone healing, collagen sponges were incorporated with bone like minerals such as hydroxyapatite (HAp), tricalcium phosphate and octacalcium phosphate ${ }^{[39-41]}$. Nano HAp can be incorporated into collagen matrix through in situ precipitation methods or directly blending the HAp along with collagen ${ }^{[42]}$.

Apart from bone tissue engineering, collagen based scaffolds are used for ocular tissue engineering, wound healing and neural tissue engineering ${ }^{[20,43]}$. Chen et al. fabricated collagen based scaffolds and successfully demonstrated their application in ocular tissue engineering ${ }^{\text {[44] }}$ Tobramycin, which is an antibiotic drug was covalently grafted with collagen using EDC/NHS and employed for ocular tissue engineering ${ }^{[45]}$. Collagen composite fabricated using oxidized cellulose was successfully utilized wound tissue engineering application ${ }^{[29]}$. Hydrogel based collagen formulation also employed for biomedical application ${ }^{[31]}$. Manufacturing human organs or tissues to replace the malfunctioning or damaged organ is one of the current research areas of interest in bioengineering. 3D bioprinting technique allows fabricating customized biomimetic structure using bioink. Bioink contains growth factors, cells and biomaterials. Collagen is widely employed as a biomaterial for the fabrication of bioink and bioprinting. Kim et al. bioprinted collagen scaffolds containing MG63 and human adipose stem cells as shown in the Figure 1d. Furthermore, the collagen allows the proliferation of the cells as shown in the Figure $1(\mathrm{e}, \mathrm{f}){ }^{[32]}$. Rhee et al. 3D bioprinted collagen scaffolds along with fibrochondrocytes and the constructs are robust and mechanically stable ${ }^{[46]}$. Systematic analysis of collagen proved that it is one of the decisive biopolymeric materials for the fabrication of wide range of formulations for biomedical applications.

\section{Gelatin}

Gelatin is biodegradable, nontoxic and FDA approved material. It is mainly extracted from bovine or porcine sources through acid (Type A gelatin) or basic (Type B gelatin) hydrolysis ${ }^{[47]}$. Other sources such as bones, fins, jelly fish and sea urchin have been utilized for the extraction of gelatin ${ }^{[47]}$. Hydrolysis of collagen to gelatin leads to the three major forms of 
gelatin as follows: i) $\alpha$ form (randomly coiled 3 independent $\alpha$ chain with molecular weight of $\sim 110000 \mathrm{~g} / \mathrm{mole}$ )), ii) $\beta$ form (two $\alpha$ chain linked via covalent bond with molecular weight of $\sim 200000 \mathrm{~g} / \mathrm{mole}$ ), and iii) $\gamma$ form (three chains linked by covalent bond with molecular weight of $\sim 300000 \mathrm{~g} / \mathrm{mole})^{[47,48]}$. The amino acid sequences are 'Gly-X-Y', the proline occupies X or Y position and the hydroxyl proline is specific to Y position. The tryptophan is absent in Gelatin [49]. The uncrosslinked gelatin gels are thermoreversible ${ }^{[50,51]}$. Typically, the random coil structure can partially recover to collagen like helical structure during cooling. The mechanical properties of gelatin are highly related to their supramolecular structure. Decrease the degree of helicity of gelatin for instance diminishes the mechanical properties (Ultimate tensile strength) [52].

Gelatin displays properties such as gel forming, thickening, emulsifying and foaming. The isoelectric point of Type A gelatin ranges between the $\mathrm{pH} 7$ and 9, whereas the isoelectric point of type $\mathrm{B}$ gelatin ranges between the $\mathrm{pH} 4.7$ and 5.4. The cationic or anionic gelatin can be synthesized based on the extraction conditions. Charged gelatin (cationic or anionic) is imperative for loading various therapeutic molecules through electrostatic interaction. Unlike collagen, gelatin displays good stability at high temperature and at wide range of $\mathrm{pH}$. Synthetic polymers such as poly( $\varepsilon$-caprolactone), polymethyl methacrylate and polyacrylonitrile could be grafted on gelatin backbone through "grafting from" (polymerization proceed on the functional surface of the substrate) or "grafting to" (grafting end functionalized polymer to the substrate) or "grafting thorough" techniques ${ }^{[53-57]}$. Gelatin based formulations are highly water soluble. Hence, crosslinking is required following the classical methods as previously mentioned for collagen.

Gene therapy widely used to modulate the gene expression and knocking out the improperly functioning gene ${ }^{[58]}$. Polyethyleneimine functionalized gelatin nanoparticles possess high positive zeta potential $(42 \mathrm{mV})$, enables the loading of DNA (negatively charged) and results in high transfection efficiency ${ }^{[58]}$. It shows that the gelatin based formulations are suitable as a vector for gene delivery. Electrospun fibers, porous foams, hydrogel films of gelatin formulations are widely used for biomedical and therapeutic molecule delivery applications. ${ }^{[59]}$ Methacryloyl group grafted gelatin known as gelatin methacrylate (GelMA) had been employed for 3D printing, hydrogel and microgel application. ${ }^{[60,61]}$ Divito et al. microfabricated blood 
vessel using GelMA. The fabricated blood vessels displayed neoangiogenesis and other processes related to blood vessel maturation ${ }^{[62]}$. Gelatin electrospun fibers loaded with antibiotic drugs (ciprofloxcacine) display excellent antibacterial activity ${ }^{[63,64]}$. Gelatin electrospun fibers display poor mechanical properties which can be improved by reinforcing with 2D material such as graphene oxide and boron nitride ${ }^{[65,66]}$. Ultraheat treatment of gelatin reduces infectivity. It displays non antigenic behavior and is susceptible for the degradation by protease ${ }^{[51]}$. The gelatin sponge based products such as Gelfoam ${ }^{\circledR}$, Gelita-Spon ${ }^{\circledR}$ and Surgifoam ${ }^{\circledR}$ (Ethicon) are currently available hemostatic products in the market.

\section{Keratin}

Keratin is a fibrous structural protein. It is a major constituent of quills, hair, hooves, claws, epidermal layer and horn. It also prevents epithelial cells from stress. Polypeptides chains are arranged as $\alpha$ - helices ( $\alpha$-keratin) or pleated beta sheets ( $\beta$-keratin) in keratin ${ }^{[67]}$. Keratin mainly contains proline, glycine and serine aminoacids. It has also a high concentration of cysteine residues (about 7-12\% mol.) ${ }^{[68]}$ In $\alpha$-keratin, coiled coil structures are formed by twisted two polypeptide chains, whereas collagen fibrils are formed by the three $\alpha$ - helices. $\beta$ keratin is tougher than $\alpha$-keratin. McKittric et al. reviewed the structure of keratin ${ }^{[69]}$. The structure of the $\alpha$-keratin can be explained as shown in the figure 2 and briefed as follows: i) individual $\alpha$-helices are right handed, ii) left-handed coiled-coil dimers are formed by the two individual right-handed $\alpha$-helix polypeptide which are further crosslinked by disulfide bonds, iii) protofilaments are formed through the end-to-end or side-by-side aggregation of dimers via sulfide crosslinking, and iv) lateral association of two protofilaments forms protofibrils and four protofibrils associated into circular or helical fashion to form intermediate filament of $7 \mathrm{~nm}$ diameter. Intermediate filaments are basic structural units which are embedded in amorphous keratin matrix ${ }^{[69]}$. $\beta$-strands are positioned side-by-side, linked through intermolecular hydrogen bond and form the pleated $\beta$ sheets.

Keratin is insoluble in water, it has weak acidity. It is resistant to trypsin or pepsin. Keratin has been extracted from various sources through reduction, microwave irradiation, alkali extraction, steam explosion, sulfitolysis and ionic liquids approaches. ${ }^{[68]}$ Shavandi et al. published a detailed review about the pros and cons of various extraction procedures of 
keratin. ${ }^{[68]}$ Shavandi et al. demonstrated that the mercaptoethanol effectively extracts cystine from wool keratin in comparison to potassium thioglycolate. Further, it was demonstrated that the high temperature and the $\mathrm{pH}$ during the extraction degrade the protein and lanthionine (thioether dimer of cysteine). Incorporating surfactants along with mercaptoethanol such as sodium dodecyl sulfate and urea decreases the oxidation of keratin ${ }^{[68]}$. Keratin extracted from various sources had been employed for the fabrication of biomaterials due to their biocompatibility, biodegradability and ability to facilitate cell attachment and proliferation. ${ }^{[70]}$ Keratin scaffolds are stabilized using the crosslinkers such as ethylene glycol diglycidyl ether, glutaraldehyde, glyoxal, dialdehyde starch, transglutaminase and formaldehyde ${ }^{[68]}$. Oxidized cellulose nanocrystal plays a dual role as reinforcing agent and crosslinker with keratin ${ }^{[71]}$. Thiol functional groups of cystine in keratin allow the surface modification using diverse range of chemical moieties for the fabrication of hydrogel ${ }^{[72]}$. Functional molecules can be loaded on the keratin using thiol-ene click chemistry reactions. ${ }^{[73]}$ Schaller et al. demonstrated the grafting of polyacrylonitrile on keratin surface which also shows that the keratin functional groups are readily available (after the reduction of disulfide bond) for further modifications. ${ }^{[7]}$

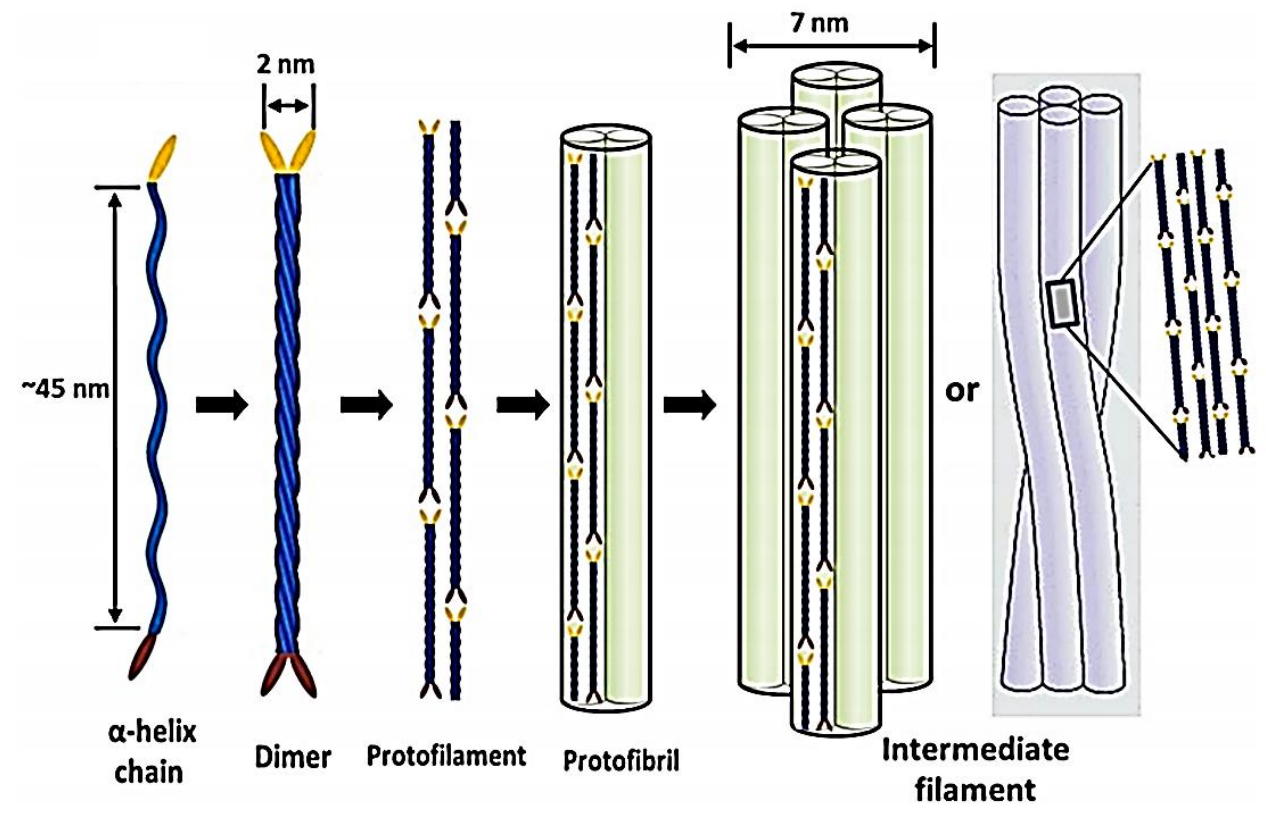

Figure 2. Hierarchical arrangement of Keratin. ${ }^{[67]}$ 
Various formulations of keratin such as films, hydrogel, electrospun fibers and composites are fabricated for biomedical applications. ${ }^{[68]}$ For instance, amniotic membrane has been utilized for the ocular surface reconstruction. Keratin films are transparent, display high mechanical properties and good cell migration ability in comparison to amniotic membrane. ${ }^{\text {[75] }}$ Keratin is negatively charged (above the $\mathrm{pH}$ of isoelectric point 3.8) and used as a polyelectrolyte for the deposition over a positively charged surface through layer by layer deposition method. ${ }^{[68]}$ Yang et al. demonstrated the layer by layer deposition of keratin on quartz film and discussed that keratin coating can provide biocompatible surface suitable for tissue engineering ${ }^{[76]}$. Drugs such as anti-proliferative drug (Paclitaxel) and Diclofenac are successfully incorporated into keratin or water soluble keratose through electrostatic interaction ${ }^{[77,78]}$. Keratin has been blended with other biopolymers such as gelatin, chitosan, silk fibroin and alginate in order to ameliorate their physical properties such as swelling and flexibility of the scaffolds. ${ }^{[79-81]}$ Keratin based scaffolds are successfully demonstrated for nerve regeneration. ${ }^{[82]}$ Park et al. proved that keratin hydrogel enhances fibroblast proliferation and collagen synthesis in rat model making it suitable material for wound tissue engineering. ${ }^{[83]}$ Placone et al. successfully 3D printed keratin scaffolds using lithography technique ${ }^{[84]}$. $\operatorname{KeraStat}(\mathrm{R})$ (KeraNetics) is the wound dressing keratin based formulation in clinical trial phase.

\section{Silk and fibroin Sericin}

Silk is a protein fiber produced by silkworms, spiders, mites, fleas and scorpion. Proteins extracted from spider silk, Bombyx mori or mulberry silk and non-mulberry silks had been explored for biomaterial fabrications. Spider silk such as major ampullate glands silk (MA silk), dragline silk and flagelliform silk are pivotal for the construction of spider web. Structural arrangement of oligopeptides varies depending on the type of silk. For example, MA silk possesses $\beta$-sheet where Flag silk is amorphous. ${ }^{[85]}$ MA silks are decisive for the construction of frame in spider web ${ }^{[86]}$. Spidroins are the important protein constituent of spider silk. It is secreted and stored as a proteins solution in specific glands of spider ${ }^{[87]}$. Alanine and glycine are the abundant amino acids in spidroin (molecular weight $>200 \mathrm{kDa}$ ). ${ }^{[88]}$ Glycine rich regions are amorphous whereas, alanine rich regions form crystalline structures. Spider silk fibers display higher toughness than Kevlar fibers. The extensibility and hierarchical arrangement of spider silk 
is shown in the Figure 3b. Various explanations are postulated for the extensibility of spider silk : i) stretching of amorphous region shifts random coil/helix confirmation into extended helix or $\beta$-strand confirmation ${ }^{[89]}$ and ii) nano fibrillary morphology of silk thread responds to the applied stress which decreases the fiber diameter and allows to align nanofibrils to the thread axis ${ }^{[90]}$. The organization of protein sequences plays a key role in oligopeptide arrangement $(\alpha-$ helices or $\beta$-sheet) and affects the mechanical properties of silk fibers. ${ }^{[86,}{ }^{91]}$ For example, oligopeptides sequence (GA) $\mathrm{n} /(\mathrm{A})$ form $\alpha$-helices, $\beta$-sheet in solution and in assembled fibers respectively and $\beta$-sheet possess high mechanical property.

Bombyx mori silk possesses inner core known as fibroin which are formed by fibroin fibrils as shown in Figure 3a. Fibroin fibrils encompass light ( $25 \mathrm{kDa})$ and heavy ( 325-350 $\mathrm{kDa}$ ) chains which are linked by a single disulfide bond. Silk fibroin displays two confirmations known as silk I and silk II. Silk I is water soluble. It displays $\alpha$-helix conformation and founds in silk gland. Silk II displays crystalline anti-parallel beta-sheet confirmation and distributed in spun silks which are insoluble ${ }^{[92,93]}$. Core fibroin is covered by glue like protein known as sericin which helps the fiber to glue together in cocoon as shown in Figure 3a. Sericine is rich with amino acid serine with a molecular weight ranges between 10 and $300 \mathrm{kDa}{ }^{[94,}{ }^{95]}$. It is antibacterial and UV resistant. Sericin can be removed from the silk fibers through degumming process using dilute sodium carbonate solution or urea, citric acid and sodium oleate ${ }^{[96]}$. 
(a)
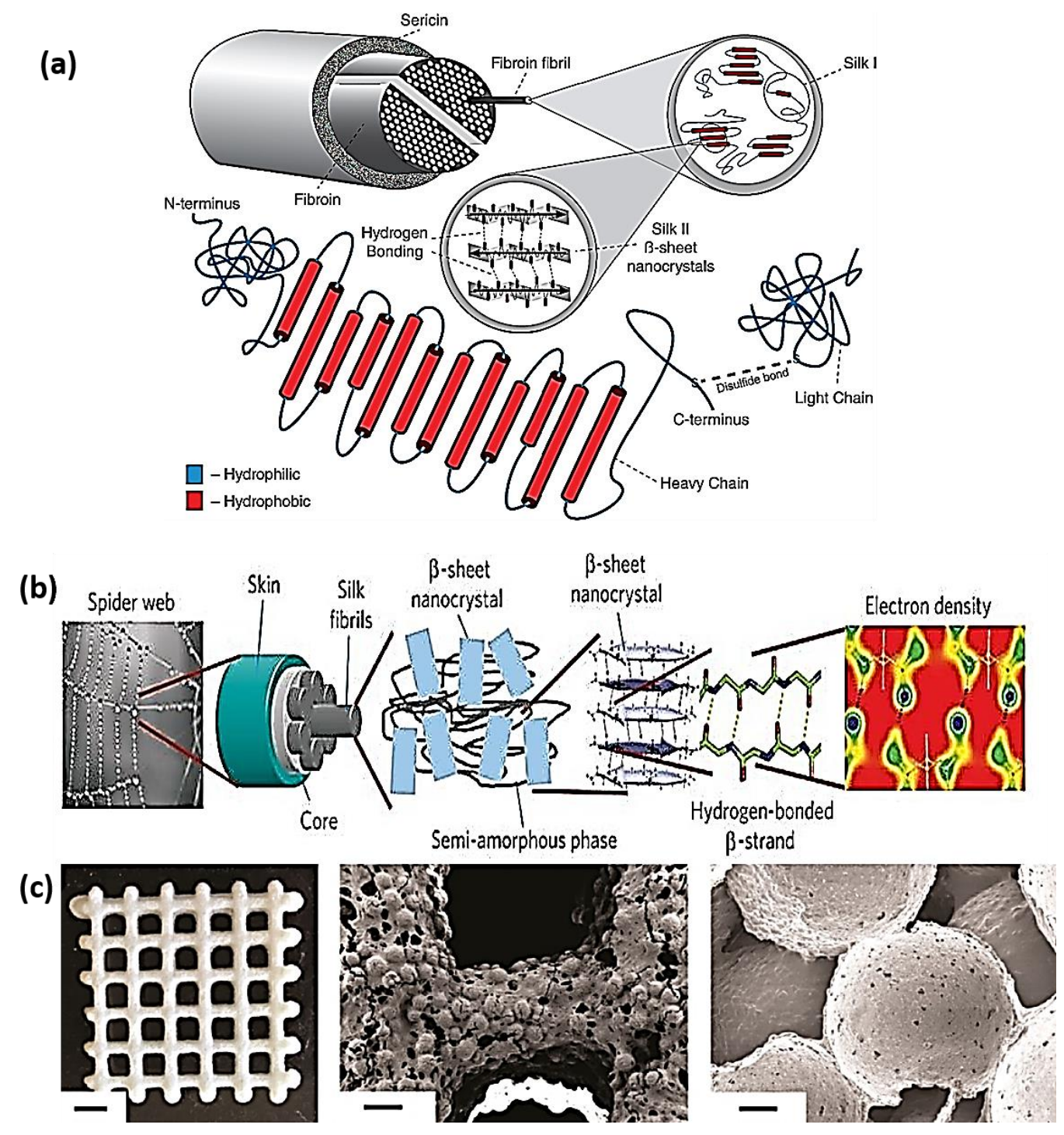

Figure 3. Hierarchical assembly of silk from (a) worm and (b) Spider, (c) 3D printed silk fibroin scaffolds ${ }^{[97]}[94,98]$

Solvents such as lithium bromide, formic acid, ionic liquids and ternary solvent system $\mathrm{CaCl}_{2} /$ Ethanol/Water are employed for the dissolution of silk fibroin ${ }^{[92,}{ }^{99]}$. The stability of the silk film fabricated using silk fibroin can be increased by annealing, which converts silk I to crystalline silk II inducing the improvement of tensile strength, Young modulus and strain ${ }^{[92]}$. In general, methanol or ethanol and steam autoclaving are used to the annealing of the silk fibroin films. SERI ${ }^{\circledR}$ is one of the silk formulation available in market ${ }^{[99]}$. Various formulations of silk fibroin such as capsule, sphere, foam, film, hydrogel and fiber are fabricated for biomedical 
applications. Silk fibroin nanoparticles are loaded with various therapeutic molecules for controlled delivery. For example, silk nanoparticles loaded with doxorubicin (anti-cancer drug) display improved cell uptake of nanoparticles and facilitate cytotoxicity of cancer cells ${ }^{[100]}$. Wenk et al. incorporated insulin as growth factor in silk nanoparticles and demonstrated a constant release for 7 weeks ${ }^{[101]}$. Fibroin, spidroin and sericin extracted from various silk sources are used for the fabrication of scaffolds for tissue engineering applications ${ }^{[102-106]}$. Wang et al. extracted fibroin from Bombyx mori silkworm and utilized to fabricate 3D scaffold for cartilage tissue engineering ${ }^{[107]}$. Hydroxyapatite has been incorporated with silk fibroin scaffolds which enhanced the differentiation of human mesenchymal stem cell into osteogenic lineages ${ }^{[108]}$. Silk fibroin based scaffolds were also fabricated using 3D printing technique. Sommer et al. fabricated silk fibroin scaffolds using extrusion based 3D printing. Furthermore, removal of sacrificial templates (wax) from the $3 \mathrm{D}$ printed silk fibroin construct results to the porous structure as shown in the figure $3 c^{[98]}$. Silk also mixed with various other biopolymers such as gelatin, alginate to achieve the rheological characters suitable for 3D printing ${ }^{[109]}$. Acrylation of silk fibroin favors the 3D printing of silk through lithography technique. Recently, Kim et al. succeeded to graft methacrylate using glycidyl methacrylate and utilized digital light process $3 \mathrm{D}$ printing to fabricate silk based scaffolds ${ }^{[10]}$. Silk also utilized for the fabrication of bioink. Enzymatic (tyrosinase) crosslinking of mesenchymal progenitor cells encapsulated silk fibroin solution improves the gelation which is crucial for bioprinting ${ }^{[111]}$.

\section{Elastin}

Elastin is the major component of the elastic fibers, provides mechanical strength and elasticity to the connective tissues. ${ }^{[12]}$ The distribution of the elastin in human system is as follows: $70 \%$ of the dry weight of elastic ligaments, about 50\% of large arteries, $30 \%$ of lung, and 2 to $4 \%$ of skin. ${ }^{[113-115]}$ Elastin performs a vital role in maintaining the structure and biochemistry of the tissue. Elastin is responsible for maintaining the elasticity of skin lungs, blood vessels etc. ${ }^{[116-118]}$ Further elastin peptides were responsible for keratinocyte differentiation and chemotaxis, cell adhesion and mesenchymal stem cell differentiation. ${ }^{\text {[119-121] }}$ The elastin matrix plays a vital role in the shape, the distribution, the alignment and the arrangement of cells within tissues and helps the cell infiltration and clustering. ${ }^{[122]}$ 
Elastin based composites has been fabricated in different shapes as films/sheets, particles, fibers, hydrogel, tubes, and 3-D matrix by using solvent casting, electrospinning, freeze-drying and 3-D printing techniques. Several cross-linking agents such as glutaraldehyde, bis (sulfosuccinimidylsuberate) (BS3), 1-ethyl-3-(3-dimethylaminopropyl) carbodiimide/Nhydroxysuccinimide (EDC/NHS) and hexamethylene diisocyanate (HMDI) are the most used. [123] The utilization of the elastin was mainly considered for promoting skin regeneration, organization of hepatocytes and blood vessel engineering [124-130]. Electrospun tropoelastin possesses physical, mechanical and biological properties similar to the dermis. It has shown improved mechanical properties, enhanced in vitro properties such as cell proliferation and migration, and good in vivo properties such as mild inflammatory response, collagen deposition ability and angiogenic properties resulting in rapid wound-closure. It was utilized to improve skin tissue regeneration. ${ }^{[131]}$ Collagen/Elastin composite cross-linked by EDC/NHS has been used for the tissue engineering of small diameter blood vessels. ${ }^{[132]}$ Elastin also mixed with synthetic biodegradable polymers to facilitate their physical properties. Poly ( $\varepsilon$ caprolactone)(PCL)/elastin 3-D composites prepared by impregnating elastin on the PCL matrix which support the growth and adhesion of primary articular cartilage chondrocyte and helping cartilage regeneration ${ }^{[133]}$. Further, electrospun poly(caprolactone)-elastin composite which possess the fiber diameter of about $519 \mathrm{~nm}$ support the growth of embryonic chick dorsal root ganglia and promoting neurite outgrowth which is a suitable biomaterial for peripheral nerve regeneration ${ }^{[134]}$.

Electrospun tropoelastin matrix was used as delivery vehicles for carrying the adiposederived stem cell to aid the healing of dermal wound. ${ }^{[135]}$ Electrospun tubular scaffolds made of multilayer composites blends of polyglyconate, gelatin and elastin has been used to mimic the natural structure of artery. It shows the mechanical properties similar to the artery and hence were used in vascular tissue regeneration. ${ }^{[136]}$ Biocapsules prepared from solubilized elastin by freezing and lyophilization displayed different incorporation and releasing ability of compounds from the wall and the lumen of the biocapsule. Here, peroxidase labeled immunoglobulin (IgG) was loaded on the capsule wall followed by the loading of alkaline phosphatase-labeled IgG. The release was triggered by digesting the capsule with the enzyme ${ }^{[137]}$.Stimuli-responsive polymer matrix has been exploited recently for the development of composites for drug delivery and tissue engineering application. Bandiera et al. developed bioactive molecules incorporated 
human elastin-like polypeptides (HELP) and demonstrated the proteolytic stimuli responsive delivery of therapeutic molecules ${ }^{[138]}$. Composite matrix comprising human elastin-like polypeptides (HELP) hydrogel and poly-L-lactic acid (PLLA) electrospun was developed to combine the superior features of two structures which can be used for delivery of therapeutic molecules ${ }^{[139]}$.

\section{Fibrin}

Fibrin, one of the fibrous proteins, is the key component of the coagulation cascade. Fibrin is an insoluble protein derived from soluble fibrinogen after tissue injury in order to cease the bleeding. On the site of injury, the coagulation cascade is initiated by the formation of insoluble fibrin matrix from its soluble precursor fibrinogen by the action of one serine protease: the thrombin ${ }^{[140]}$. Fibrinogen is composed of a pair of $\mathrm{A} \alpha$ chain, $\mathrm{B} \beta$ chain and $\mathrm{C} \gamma$ chain linked by disulphide bond ${ }^{[141]}$. Furthermore, it has two distal globular regions (D domain) and a central globular region (E domain) connected by $\alpha$ helical coiled coil as shown in Figure 4A. The E domain is made of $\beta$ and $\gamma$ nodules linked by non-covalent interaction. Polymerization of fibrin is initiated by the removal of $\mathrm{A}$ and $\mathrm{B}$ fibrinopeptide from $\mathrm{N}$ terminal of $\mathrm{A} \alpha$ chain and $\mathrm{B} \beta$ chain exposing the Gly-Pro-Arg-Pro sequence (GPRP), peptide sequence known as knob"A" and GlyHis-Arg-Pro (GHRP) peptide sequence known as knob "B" respectively. The knob "A" and knob "B" have tendency to bind to the corresponding complementary sequences known as hole "a"

present in $\gamma$ nodules and hole " $b$ " present in $\beta$ nodules of other fibrin molecules. This binding induces the polymerization of fibrin as shown in Figure 4B. Hence, during polymerization, binding of the complementary sites (A:a and B:b) will produce half staggered arranged fibrin monomers ${ }^{[142]}$.

Fibrin based hydrogel system seeded with cells are widely used in cardiac tissue engineering. However hydrogels are mechanically weak and fail due in the cardiac environment. ${ }^{[143]}$ To overcome mechanical instability, designing the biomaterial that mimic the property of myocardial tissue was essential for the development of myocardial implant. Chrobak et al. prepared a mechanically stable biomaterial for myocardial tissue repair by layering the fibrin microthreads within the fibrin hydrogel. The prepared fibrin microthread incorporated fibrin hydrogel exhibited mechanical properties comparable to that of myocardial tissue. Furthermore, the developed biomaterial supports the contraction and orientation of cells ${ }^{[144]}$. Fibrin incorporated with proteinase inhibitor, $\varepsilon$-aminocaproicacid (ACA) loaded chitosan 
tripolyphosphate nanoparticles prevents the degradation of fibrin matrix with the release of ACA. In vitro studies of the prepared material with cementoblasts revealed that it promotes the differentiation of cementoblasts with high expression of Runx2, osterix, osteocalcin, and bone sialoprotein (BSP) and can be employed in periodontal regeneration ${ }^{[145]}$. A complex hydrogel system was prepared by Arunkumar et al. from nano-fibrin, calcium sulphate and chitin hydrogel. The developed composite hydrogel exhibited rheology of the shear thinning gel with elastic modulus of $15.4 \pm 0.275 \mathrm{kPa}$. In vitro studies using rabbit adipose derived mesenchymal stem cells (rASCs) showed better cell attachment, increased alkaline phosphatase expression analysis and enhanced angiogenesis revealing the capacity of the material for bone repair ${ }^{[146]}$.
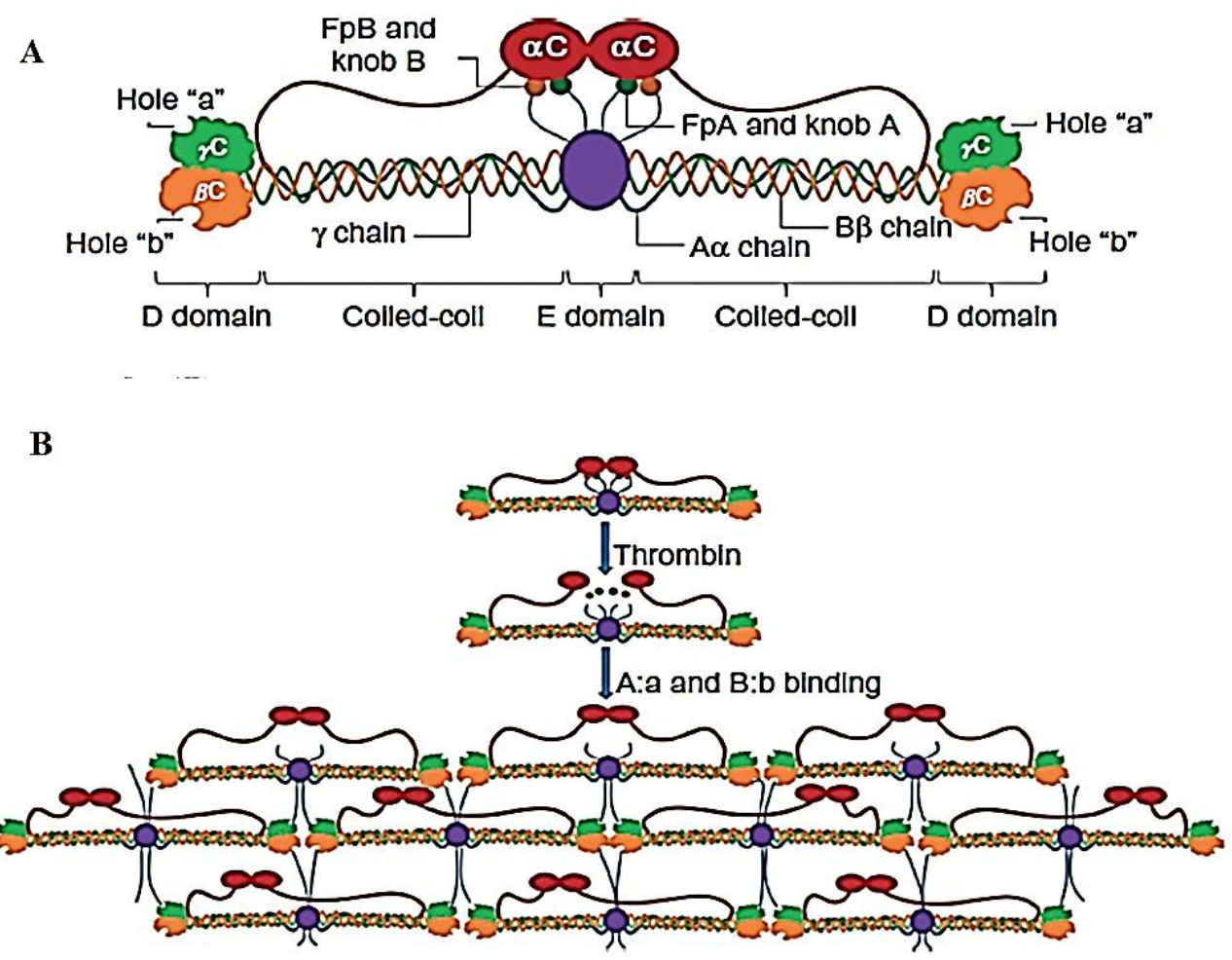

Figure 4 (A) Structure of fibrinogen (B) Fibrin polymerization. ${ }^{[147]}$ 
Fibrin network also acts as a scaffold for the growth of neutrophil, macrophage and fibroblast, which will secrete fibronectin, collagen and other ECM components to repair the damaged tissue. Because of its bioactive properties and its ability to tune material properties of the obtained fibrin gel, fibrin has been used for wide range of biomedical applications. Various parameters such as porosity, fiber thickness and degree of branching have been varied by modifying the polymerization dynamics which have its influence on the mechanical properties. [148-152]. Fibrin has been used as a sealant in surgery to induce hemostasis, closure of wounds and sealing tissue. It is used as a tissue adhesive for sealing the tissues to minimize the bleeding of blood in surgery. ${ }^{[153]}$ Fibrin nanoparticles loaded VEGF growth factor incorporated into chitosanhyaluronic acid sponge resulted in the sustained release of the growth factor. It helps in facilitating the angiogenesis and thereby aiding healing of wound. ${ }^{[154]}$ Fibrin layer containing VEGF and bFGF were layered over synthetic poly (ether) urethane (PEtU) and polydimethylsiloxane (PDMS) composites by spray, phase-inversion technique and deposition. The obtained material was found to acquire the mechanical properties from the synthetic polymer and the sustained release ability of the pro-angiogenic growth factors from the layered fibrin. ${ }^{[155]}$ Fibrin based hydrogel was used for delivering cells. Kim et al. utilized fibrin containing osteoblast cells for the regeneration of bone defect and they observed that the fibrin shows better results in comparison to that of autologous bone graft. ${ }^{[156]}$

\section{Milk Protein}

Milk is an emulsion produced from the mammary glands of mammals. It contains butterfat globules, carbohydrates, minerals and protein aggregates. Casein and whey proteins are the major protein constituent in milk.

\section{Casein}

Casein is used for a family of secreted phosphoproteins which bind with the calcium. It is found in mammalian milk. ${ }^{[157]}$ It is insoluble and represent $80 \%$ of the total bovine milk proteins (corresponding to $2.75 \%$ of total milk components). ${ }^{[158]}$ Casein is composed of $94 \%$ proteins and of $6 \%$ low molecular weight compounds such as colloidal calcium phosphate. Casein exists in four fractions, $\alpha \mathrm{S} 1-, \alpha \mathrm{S} 2-, \beta-$, and $\kappa$-casein in cow milk with 4:1:4:1 weight proportions 
respectively. Those protein fractions differ from each other in aminoacid and phosphorus carbohydrate content as well as in primary, secondary and tertiary structures. ${ }^{[159,160]}$ Casein fractions are amphiphilic ${ }^{[161,162]}$. Among the casein fractions, only $\kappa$-casein can form disulfide bonds with its two cysteine moities. ${ }^{[163,164]}$ Due to the scarcity of $\alpha$-helixes and $\beta$-sheets in its secondary structures, caseins are flexible. Random-coil peptides have the ability to interact through intermolecular electrostatic, hydrogen and hydrophobic interactions. ${ }^{[160]}$ Caseins are present in energy favorable conformation making it susceptible to thermal denaturation. ${ }^{[165]}$ Their subunits self-assemble to form an amorphous and stable aggregate termed casein micelle with a radius from 50 to $500 \mathrm{~nm}$ and a molecular weight of 103 to $39106 \mathrm{kDa} .^{[163,165]}$ Casein micelles are made of thousands of casein molecules forming $94 \%$ of the micelle and the remaining $6 \%$ accounts for amorphous calcium phosphate to which protein molecules bound by phosphoryl residues. ${ }^{[157,162,166]}$ In casein micelle, $\alpha \mathrm{S} 1, \alpha \mathrm{S} 2$ and $\beta$-casein are located in the interior part while $\kappa$-casein is located on the periphery (Figure 5a) projecting like a hairy layer which stabilizes sterically the micelle. ${ }^{[162]}$

(a)

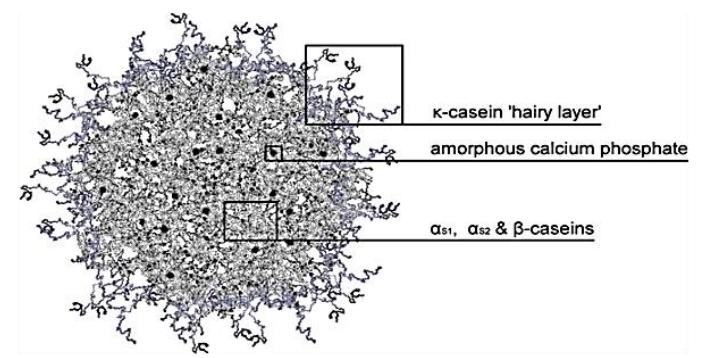

(b)

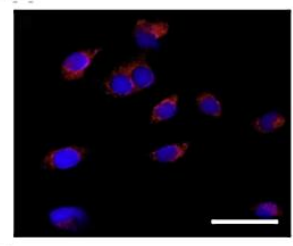

(e)
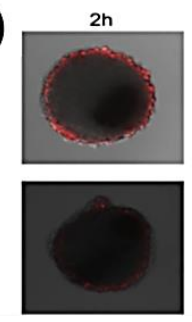

(c)
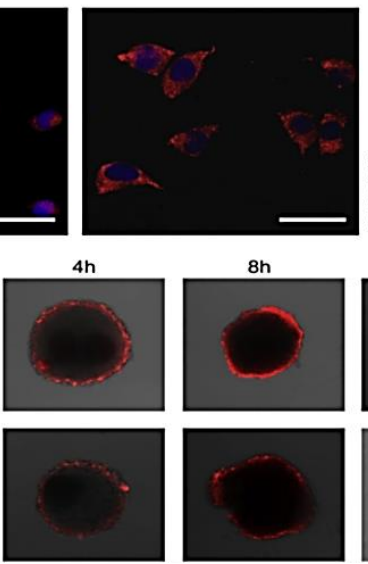

(d)
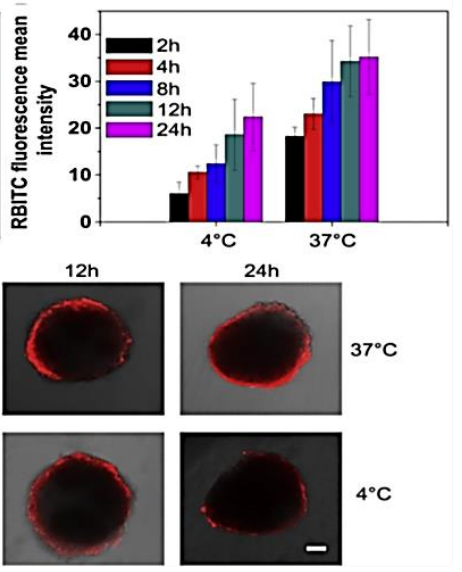

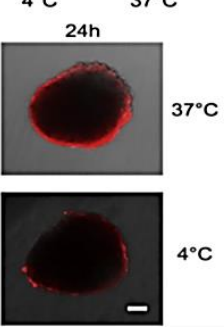

Figure 5. (a) Graphical representation of casein micelle, Fluorescence images of SHSY5Y cells with casein nanoparticles labeled Rhodamine B after $4 \mathrm{~h}$ incubation at (b) $37{ }^{\circ} \mathrm{C}$ and 
(c) $4{ }^{\circ} \mathrm{C}$; (d) Mean fluorescence intensity in tumor spheroids for RBITC-labeled casein nanoparticles at $37{ }^{\circ} \mathrm{C}$ and $4{ }^{\circ} \mathrm{C}$. Scale bar $=50 \mu \mathrm{m}$. (e) Fluorescence images of tumor spheroids incubation with casein nanoparticles labeled by Rhodamine $\mathrm{B}$ at $37{ }^{\circ} \mathrm{C}$ and at $4{ }^{\circ} \mathrm{C}[167,168]$

Casein has been used for the encapsulation of biologically active agents for the biomedical applications. Zhen et al. developed casein nanoparticles loaded cisplatin by cross-linking using transglutaminase. The synthesized nanoparticles were found to be stable, spherical, with $10 \%$ drug loading capacity. Human derived neuroblastoma cell line (SH-SY5Y cells) were incubated with Rhodomine B loaded casein nanoparticles at $4{ }^{\circ} \mathrm{C}$ and $37{ }^{\circ} \mathrm{C}$ to study the effect of nanoparticles. Fluorescence analysis reveals the uptake of nanoparticles within the cells and also the deeper infiltration of the nanoparticles onto the tumor spheroids (Figure 5e). In vivo studies in hepatic tumor bearing mouse model revealed deep penetration of the nanoparticles into tumor tissue. The nanoparticles loaded cisplatin inhibited the growth of tumor cells by 1.5 times then the free cisplatin ${ }^{[168]}$. Nanoparticles prepared from casein-silk fibroin loaded with carvedilol drug when administered into rats has shown 6.87 fold increasing in bioavailability of the drug when compared with that of administration of aqueous drug. The improved bioavailability of the drug makes casein-silk fibroin nanoparticles a potential carrier for the drug. Nanoparticles prepared from casein and silk fibroin through cross-linking showed increased bioavailability during in vivo experiments conducted in rats. ${ }^{[169]}$ Casein-pectin nanoparticles encapsulating rutin exhibited delayed release in simulated gastric conditions and sustained release under simulated intestinal conditions. ${ }^{[170]}$ Hence casein-pectin nanoparticles have been used as delivery vehicle of drugs by delivering selectively in the intestine leading to prevention of loss of drug in the stomach. ${ }^{[171]}$ In ex-vivo experiments, casein coated nanoparticles loaded with drugs showed enhanced permeability when compared with the uncoated nanoparticles enables the effective uptake of drug by the cell. ${ }^{[172]}$ Casein nanoparticles have been used in the preparation of floating matrix for sustained release of loaded drug. Floating matrix prepared by direct compression of spray dried alfuzosin hydrochloride loaded casein nanoparticles revealed rapid floating within 15 minutes which is lesser than the marketed ones and exhibited sustained release of alfuzosin hydrochloride for 24 hours. This forms an alternative technique for the development of floating tablet with sustained release. ${ }^{[173]}$. Being the dietary proteins, caseins are considered as Generally 
Regarded as Safe (GRAS) GRAS and shown biocompatible, biodegradable and bioresorbable properties; It can be employed as well as for the delivery of bioactive substance through oral administration.

\section{Whey protein}

Whey proteins (WPn) are extracted from milk, which contains $\alpha$-lactalbumin, $\beta$ lactoglobulin, and bovine serum albumin as a constituent. Aminoacids such as leucine, isoleucine and valine as well as sulfur containing amino acids such as cysteine and methionine are found in whey protein ${ }^{[174,175]}$. $\beta$-lactoglobulin $(B L G)$ is the major protein with the molecular weight of $18.4 \mathrm{kDa}$. BLG exists as a monomer at $\mathrm{pH} 9$ and rigid dimer at $\mathrm{pH}$ between 5.2 and 7. ${ }^{[176]}$ Fibrils of BLG display high $\beta$-sheet content. ${ }^{[177]}$ WPn are globular proteins and form amyloid like fibrils when heating at $\mathrm{pH} 2 .^{[175,178,179]}$. Heat set gels are formed by unfolding of protein through heating process followed by aggregation of unfolded proteins. Cold set gelation are induced in two steps: i) heating the protein solution at neutral $\mathrm{pH}$ or $\mathrm{pH}$ above the isoelectric point for unfolding the protein and ii) Decreasing the $\mathrm{pH}$ of the protein unfolded solution or introducing salt to facilitate the intermolecular interaction. ${ }^{[180]}$ Aggregated proteins are selfassembled into larger particles as shown in Figure 6a. It is facilitated through hydrophobic, hydrogen bonding and disulfide bonding between particles ${ }^{[181]}$. Such gelling properties of WPn are utilized for the fabrication of therapeutic molecules loaded hydrogel. 

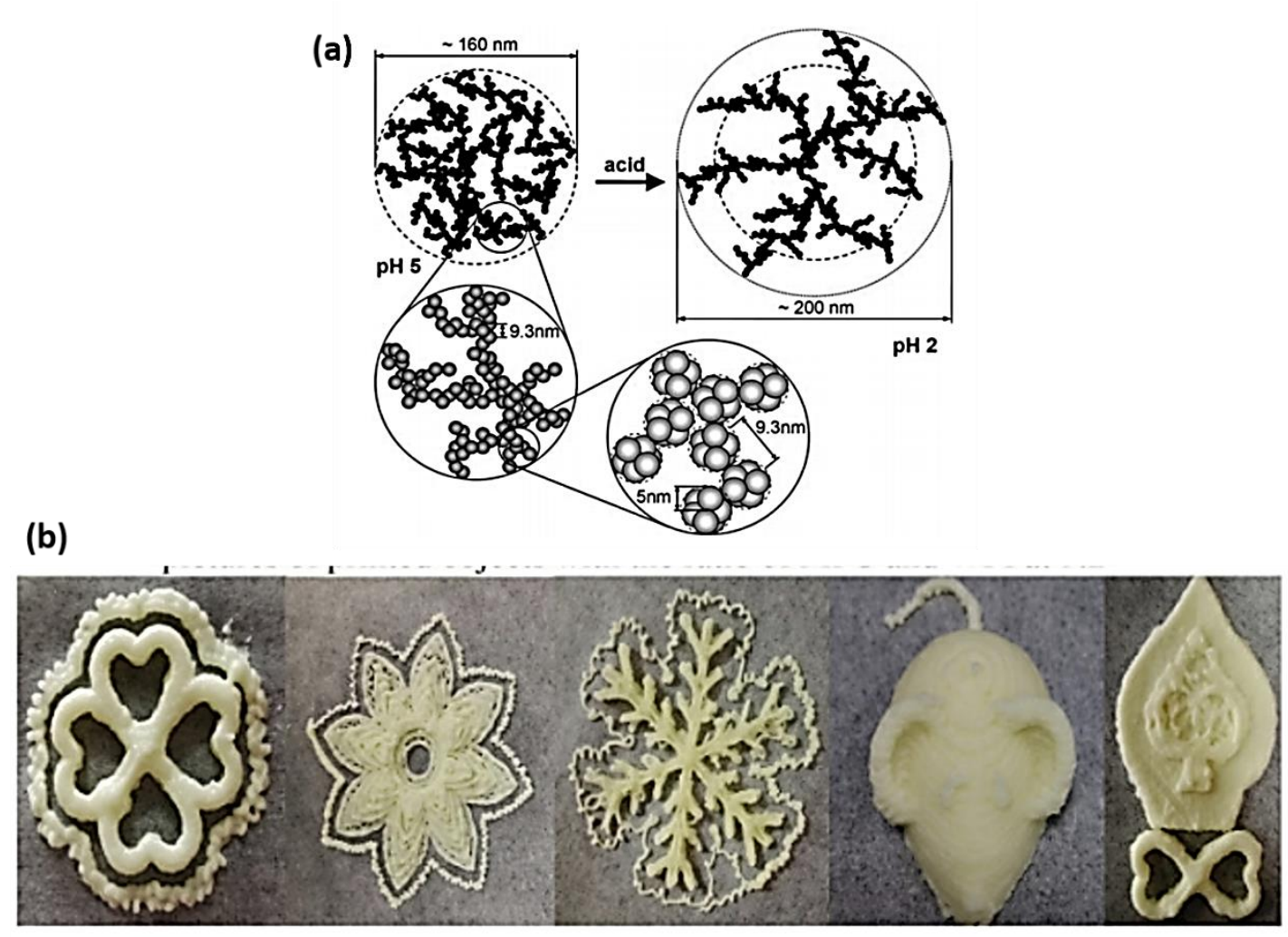

Figure 6. (a). Hierarchical assembly of aggregated WPn nanogel, (b) various 3D printed structures using whey protein isolate ${ }^{[181,182]}$

WPn displays poor tendency to form self-standing films. However, Ferreira et al. successfully fabricated self-standing films of WPn with chitosan ${ }^{[183]}$. Gilbert et al. fabricated plasticizer introduced self-standing films and proved their biocompatibility using keratinocytes and fibroblast. ${ }^{[184]}$ Nanoparticle of BLG had been utilized for the delivery of therapeutical molecule and nutraceutical delivery application. BLG nanoparticles are formed through heat induced aggregation or altering the $\mathrm{pH}$ and ionic strength of the solution ${ }^{[185]}$. Various other formulations such as electrospun fibers and microspheres were also fabricated using WPn along with synthetic and biopolymers. ${ }^{[186-188]}$ Chen et al. reported riboflavin loaded WPn/Alginate microsphere and showed the $\mathrm{pH}$ sensitive drug release due to erosion of matrix. ${ }^{[187]}$. Polycarprolactone electrospun fibers are hydrophobic; The incorporation of WPn significantly reduced the wettability of these fibers and employed for the delivery of antibiotics. ${ }^{[189]}$ Liu et al. 
demonstrated the 3D printing of whey protein using the mixture of whey protein isolate and milk protein as shown in the figure $6 b^{[182]}$.

\section{Plant proteins}

Proteins extracted from plant also found importance in biomedical applications. Similar to animal derived proteins, plant proteins display biocompatibility and biodegradability. Zein and soy proteins are the most investigated for biomedical applications.

\section{Zein}

Zein protein is mainly extracted from corn through dry milling, wet milling, alkaline treatment and dry grind treatment. It is distributed in endosperm tissue of corn. ${ }^{[190]}$ It is a prolamine (proline rich) protein, rich in glutamic acid, leucine, proline and alanine but deficient in lysine and tryptophan ${ }^{[191]}$. It displays four classes as follows: $\alpha$-zein (molecular weight between 22 and $24 \mathrm{kDa}), \beta$-zein $(17 \mathrm{kDa}), \gamma$-zein and $\delta$-zein $(10 \mathrm{kDa}) .{ }^{[192]} \alpha$-zein is soluble in $95 \%$ ethanol. $\beta$ - zein is insoluble in $95 \%$ ethanol and soluble in $60 \%$ ethanol. The proposed structure of $\alpha$ - zein is shown in Figure 7(a,b). Zein possesses abundant hydrophophic amino acid residues, it is insoluble in water and it is tasteless. ${ }^{[193]}$ However, it displays solubility in organic solvent such as ethanol, acetone, acetyl acetone and thus found importance characteristics in material fabrication. The water solubility of the zein can be improved through acid or basic hydrolysis. ${ }^{[191]}$ Zein is biodegradable by the pepsin enzyme as example. 

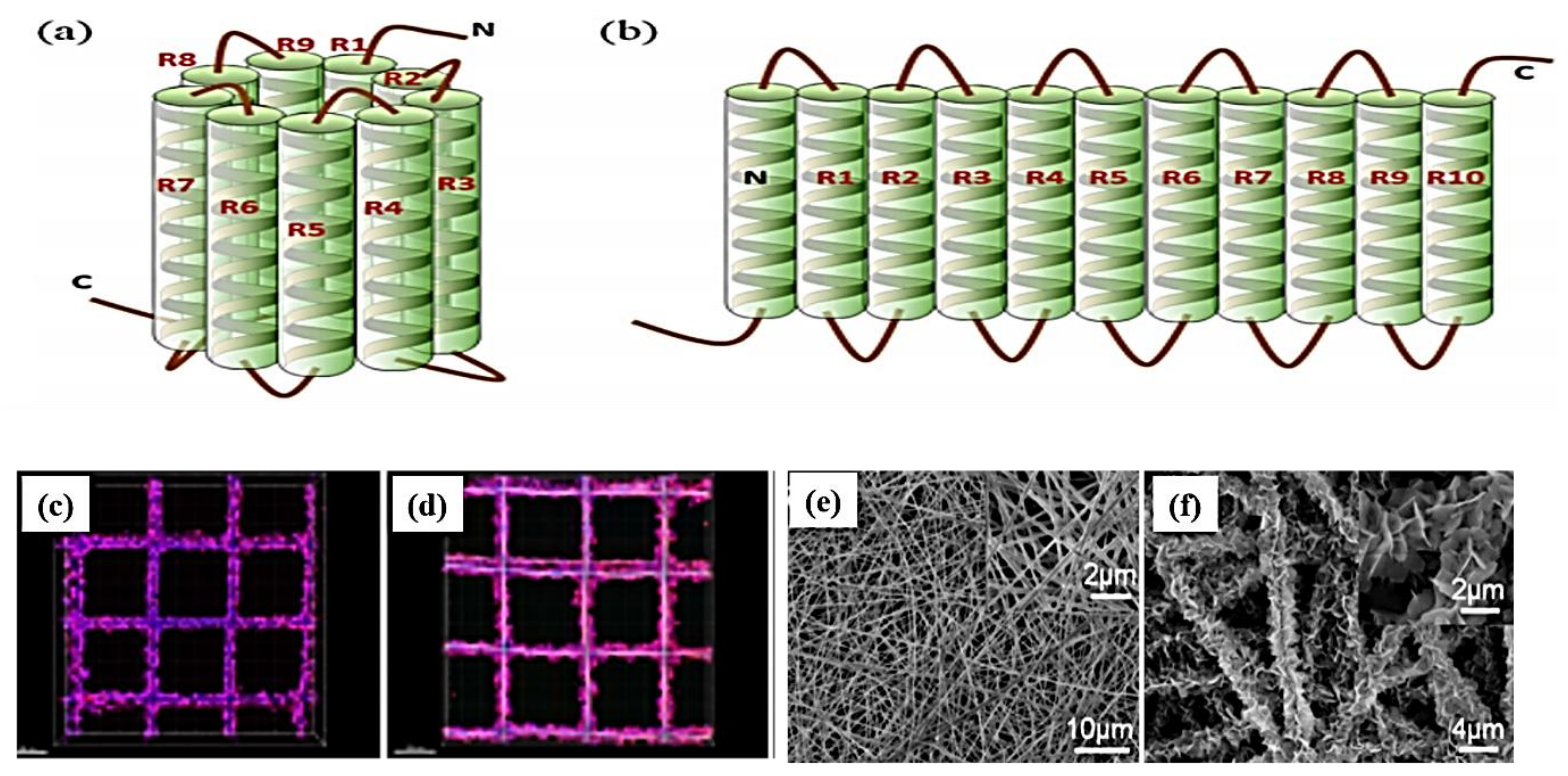

Figure 7. Proposed structure of $\alpha$-Zein (a) Cylindrical model ${ }^{[194]}$. (b) Ribbon like model, H1299 cells attached on 3D printed (c)PCL ${ }^{[195]}$, (d) 10-Zein PCL scaffolds, electrospun fibers of (e) Zein, (f) mineralized Zein fibers ${ }^{\text {[193, 195-197] }}$

Zein proteins have been utilized for the fabrication of various formulations such as film, fiber and micro/nano particles. It is a protein based thermoplastic which can be extruded into different shapes. ${ }^{[198]}$ Zein exhibits mucoadhesive behavior which found advantageous for the mucosal delivery of drugs and vaccines. ${ }^{[199,200]}$ Microspheres fabricated using zein display sustained drug release for prolonged period (8 days). ${ }^{[201]}$ Microspheres of zein are prone to degradation with pepsin enzyme. Numerous other therapeutic molecules such as proteins, peptides and vaccines are loaded and delivered using zein microsphere. ${ }^{[192]}$ Zein has been proved as an excellent carrier for poorly water soluble drugs in oral delivery. ${ }^{[192]}$ Dong et al. fabricated zein films and proved their biocompatibility by successfully culturing human liver cells and mice fibroblasts ${ }^{[202]}$. Interconnected porous scaffolds fabricated using zein allows to attach and to proliferate the mesenchymal stem cell which supports the biocompatibility of zein [203]. Incorporation of plasticizer (glycerol) facilitates the thermo rheological behavior of zein which is suitable for 3D printing ${ }^{[204]}$. The ink of Zein and PCL allows to 3D print the biocompatible construct at high voltage as shown in the figure 7c,d. PCL/Zein constructs are enzymatically degradable ${ }^{[195]}$. Furthermore, the porous scaffolds were implanted in a rabbit model and demonstrated the in vivo biocompatibility. ${ }^{[205]}$ It has been used as a coating material for the tablet 
due to its resistance to abrasion, heat and humidity. Zein composites are fabricated using synthetic polymers, biopolymers and inorganic nanoparticles, in order to ameliorate their physical properties such as young's modulus, tensile strength and gene expression. ${ }^{[206-208]}$ Zhang et al. produced Zein/HAp electrospun fibers which displayed enhanced mineralization of calcium phosphate in simulated body fluid and the electrospun fibers are biocompatible to adipose derived stem cells ${ }^{[196]}$. Quantum dots (QD) are widely utilized for bioimaging application. Indeed the toxicity thwarts the QD biomedical applications. Aswathy et al. produced zein coated biocompatible quantum dots, loaded with 5-FU Zein and demonstrated its importance for theranostic applications. ${ }^{[209]}$

\section{Soy protein}

Soy proteins (SP) are extracted from soy beans. Soy beans contains $\sim 38 \%$ of proteins, $\sim 30 \%$ carbohydrates, $\sim 14 \%$ moisture and minerals and $\sim 18 \%$ oil. ${ }^{[210]}$ Conglycinin $7 \mathrm{~S}$ and glycinin $11 \mathrm{~S}$ are the major constituent of soy protein. They display globular structure. ${ }^{[210]}$ Molecular weight of glycinine and conglycinine are in the range of 300-400 kDa and 150-250 $\mathrm{kDa}$ respectively. ${ }^{[211]} \beta$-Conglycinin exists as trimer or hexamer in solution whereas glycinine is hexamer. ${ }^{[211]}$ Conglycinin has three subunits $\left(\alpha, \alpha^{\prime}\right.$, and $\left.\beta\right)$ which are linked through hydrophobic interactions. Glycinin contains acidic or basic polypeptides linked through disulfide bond. The isoelectric point of conglycinin and glycinin are found to be 4.8 and 6.4 respectively. ${ }^{[212,213]}$ Soy proteins contain $18 \%$ basic aminoacids and $20 \%$ acidic aminoacids. ${ }^{[210,214]}$

Gelation of SP can be induced by heat induced aggregation or by varying the $\mathrm{pH}$, the salt concentration and the enzyme induced crosslinking. ${ }^{[215]}$ Gelation of soy proteins can be explained in simple steps as follows: i) denaturation of the protein, ii) Unfolding of the protein, and iii) Aggregation into fibrils which leads to gelation. ${ }^{[214,216]} \mathrm{SP}$ are stabilized using the crosslinkers such as glutaraldehyde, glyceraldehyde, transglutaminase and formaldehyde. ${ }^{\text {[217] }}$ Functional groups such as $-\mathrm{OH},-\mathrm{SH},-\mathrm{NH}_{2}$ are available in SP for functionalization and grafting. [210] Soy proteins can be covalently grafted with polycarprolactone. Furthermore, increasing the crosslinker concentration improves the young's modulus of the composite significantly. ${ }^{[218]}$ Incorporating synthetic, biopolymers and inorganic nanoparticles found to ameliorate the physical properties of soy protein composite. ${ }^{[219]}$ For example, Guerrero et al. incorporated 
glycerol and gelatin as a plasticizer to fabricate soy protein based films and enhanced the tensile strength of soy protein. ${ }^{[219]}$ Silva et al. reported a bioglass incorporated bioactive soy protein composite for bone tissue engineering application. ${ }^{[220]}$

Various formulations were reported such as interconnected 3D porous scaffolds, nano and micro hydrogel, tablet and electrospun fibers. ${ }^{[213,215,221-224]}$ Films fabricated using SP are brittle which can be improved using plasticizers such as sorbitol and glycerol. ${ }^{[225,226]}$ Gelation of soy protein can be induced using crosslinkers such as glutaraldehyde and glyceraldehyde. ${ }^{\text {[217] }}$ Electrospun fibers fabricated using SP display improved wound healing capacity. ${ }^{[223]}$ Nanogel based drug carrier system are potential candidate to permeate the cell membrane and deliver the therapeutic molecules. However selecting biodegradable and nontoxic material is imperative. SP is widely characterized material for the fabrication of nanogel based drug delivery and nutraceutical delivery applications ${ }^{[180]}$. Soy protein formulations are prone to degradation by the enzyme pepsin and pancreatin. Maltais et al. reported riboflavin loaded soy protein hydrogel and tablet. They demonstrated that the riboflavin could be released by the enzymatic degradation of the matrix. ${ }^{[22]}$. Chien et al. evaluated the in vivo performance of freeze dried soy protein scaffolds and compared with collagen scaffolds which showed that the acute immune response of soy protein scaffolds are similar to collagen scaffolds ${ }^{[221]}$. However, degree of immune response enhanced with increasing protein concentration ${ }^{[221]}$. Soy protein based scaffolds also fabricated using 3D printing. Chien et al. 3D printed soy protein scaffolds using soy protein slurry through extrusion based 3D printing ${ }^{[227]}$. Lin et al. developed thermal responsive gelling hydrogel using soy protein isolate and poly urethane based polymer. Further neural stem cells were blended along with the polymer matrix to develop bioink for 3D printing ${ }^{[228]}$.

\section{Conclusion and future perspective}

Protein based biopolymers are biocompatible, biodegradable and suitable for biomedical applications. Collagen and gelatin (denatured collagen) based materials are explored and their formulation are currently available as products in biomedical markets. Despite keratin based formulations are widely studied, further steps are to be taken for manufacturing keratin based products for biomedical applications. Keratin contains active functional groups and biological origin which can be utilized to graft various synthetic biodegradable polymers to improve the 
physical properties of keratin. Silk fibroin and sericin extracted from mulberry silk worm are extensively studied for biomedical applications. Indeed, cannibalistic nature of spider thwarts mass production of spider silk. Finding an alternate solution for the mass production and exploiting its property for the fabrication of biomaterials are crucial. Apart from mulberry silks, feasibility of nonmulberry (Eri and Muga silk) silks in fabrication of biomedical scaffolds can be

explored, due to the presence of inherent RGD (Arginylglycylaspartic acid) sequence. In-vitro synthesis of self-assembled elastin is more complex process and requires several non elastinous proteins. However, designing a patient specific fibroblast loaded and bioprinted matrix may allow producing elastin self-assembled matrix for implantation. Generally, polypeptide chain contains wide range of functional groups such as $-\mathrm{SH}, \mathrm{NH}_{2},-\mathrm{COOH}$ and $-\mathrm{OH}$ depends on the aminoacid sequence. These functional groups can be utilized for functionalizing with growth factors and synthetic polymer, which can ameliorate the physical properties of protein based biopolymer. Wide ranges of crosslinkers are available for stabilizing the protein based formulation. Globular proteins are stabilized mainly through heat induced aggregation methods. Crosslinker assisted stabilization are also often reported to stabilize globular protein. Plant derived globular proteins such as zein and soy protein display excellent physical properties. They were used for the fabrication of tissue engineering constructs. In contrary, the explorations of in vivo and clinical performance of plant derived protein materials are indispensable. Based on the literature and as reported in the review, protein based biopolymeric formulations are promising candidates for regenerative tissue engineering and drug delivery application.

ACKNOWLEDGEMENTS: We acknowledge the financial support from Indo-French Centre for the promotion of advanced research-Cefipra (Project 5608-1).

\section{References}

[1] M. G. A. Vieira, M. A. da Silva, L. O. dos Santos, M. M. Beppu, European Polymer Journal 2011, 47, 254.

[2] S. M. Choi, P. Chaudhry, S. M. Zo, S. S. Han, "Advances in Protein-Based Materials: From Origin to Novel Biomaterials", in Cutting-Edge Enabling Technologies for Regenerative Medicine, H.J. Chun, C.H. Park, I.K. Kwon, and G. Khang, Eds., Springer Singapore, Singapore, 2018, p. 161.

[3] Y. Du, S. Li, Y. Zhang, C. Rempel, Q. Liu, Journal of Applied Polymer Science 2016, 133. 
[4] G. Jung, Z. Qin, M. J. Buehler, "Mechanical Properties and Failure of Biopolymers: Atomistic Reactions to Macroscale Response", in Polymer Mechanochemistry, R. Boulatov, Ed., Springer International Publishing, Cham, 2015, p. 317.

[5] A. O. Elzoghby, W. M. Samy, N. A. Elgindy, Journal of Controlled Release 2012, 161, 38.

[6] T. J. Keane, S. F. Badylak, Seminars in Pediatric Surgery 2014, 23, 112.

[7] S. Nagarajan, D. Abessolo Ondo, S. Gassara, M. Bechelany, S. Balme, P. Miele, N. Kalkura, C. PochatBohatier, Langmuir 2018, 34, 1542.

[8] J. Biscarat, M. Bechelany, C. Pochat-Bohatier, P. Miele, Nanoscale 2015, 7, 613.

[9] Y. Li, J. Rodrigues, H. Tomás, Chemical Society Reviews 2012, 41, 2193.

[10] P. M. Kharkar, K. L. Kiick, A. M. Kloxin, Chemical Society Reviews 2013, 42, 7335.

[11] R. Sridhar, R. Lakshminarayanan, K. Madhaiyan, V. Amutha Barathi, K. H. C. Lim, S. Ramakrishna, Chemical Society Reviews 2015, 44, 790.

[12] S.-B. Park, E. Lih, K.-S. Park, Y. K. Joung, D. K. Han, Progress in Polymer Science 2017, 68, 77.

[13] U. Jammalamadaka, K. Tappa, Journal of Functional Biomaterials 2018, 9, 22.

[14] S. Nagarajan, C. Pochat-Bohatier, S. Balme, P. Miele, N. S. Kalkura, M. Bechelany, Pure and Applied Chemistry 2017, 89, 1799.

[15] S. K. Nitta, K. Numata, International Journal of Molecular Sciences 2013, 14, 1629.

[16] N. Ni, M.-J. Dumont, Waste and Biomass Valorization 2017, 8, 285.

[17] W. Friess, European Journal of Pharmaceutics and Biopharmaceutics 1998, 45, 113.

[18] M. D. Shoulders, R. T. Raines, Annual Review of Biochemistry 2009, 78, 929.

[19] M. I. Avila Rodríguez, L. G. Rodríguez Barroso, M. L. Sánchez, Journal of Cosmetic Dermatology 2018, $17,20$.

[20] R. Parenteau-Bareil, R. Gauvin, F. Berthod, Materials 2010, 3, 1863.

[21] B. D. Ulery, L. S. Nair, C. T. Laurencin, Journal of Polymer Science Part B: Polymer Physics 2011, 49, 832.

[22] A. Sionkowska, J. Skopinska-Wisniewska, M. Gawron, J. Kozlowska, A. Planecka, International Journal of Biological Macromolecules 2010, 47, 570.

[23] G. Goissis, E. Marcantonio, R. A. C. Marcantônio, R. C. C. Lia, D. C. J. Cancian, W. M. d. Carvalho, Biomaterials 1999, 20, 27.

[24] P. B. van Wachem, M. J. A. van Luyn, L. H. H. O. Damink, P. J. Dijkstra, J. Feijen, P. Nieuwenhuis, Journal of Biomedical Materials Research 1994, 28, 353.

[25] L.-P. Yan, Y.-J. Wang, L. Ren, G. Wu, S. G. Caridade, J.-B. Fan, L.-Y. Wang, P.-H. Ji, J. M. Oliveira, J. T. Oliveira, J. F. Mano, R. L. Reis, Journal of Biomedical Materials Research Part A 2010, 95A, 465.

[26] D. Y. S. Chau, R. J. Collighan, E. A. M. Verderio, V. L. Addy, M. Griffin, Biomaterials 2005, 26, 6518. [27] L. H. H. Olde Damink, P. J. Dijkstra, M. J. A. van Luyn, P. B. van Wachem, P. Nieuwenhuis, J. Feijen, Biomaterials 1996, 17, 765.

[28] A. Martínez, M. D. Blanco, N. Davidenko, R. E. Cameron, Carbohydrate Polymers 2015, 132, 606.

[29] T. Lu, Q. Li, W. Chen, H. Yu, Composites Science and Technology 2014, 94, 132.

[30] K. R. Meade, F. H. Silver, Biomaterials 1990, 11, 176.

[31] S. E. Dunphy, J. A. J. Bratt, K. M. Akram, N. R. Forsyth, A. J. El Haj, Journal of the Mechanical Behavior of Biomedical Materials 2014, 38, 251.

[32] Y. B. Kim, H. Lee, G. H. Kim, ACS Applied Materials \& Interfaces 2016, 8, 32230.

[33] C. H. Lee, A. Singla, Y. Lee, International Journal of Pharmaceutics 2001, 221, 1.

[34] W. Friedman, "Chapter 29 - Growth Factors", in Basic Neurochemistry (Eighth Edition), S.T. Brady,

G.J. Siegel, R.W. Albers, and D.L. Price, Eds., Academic Press, New York, 2012, p. 546.

[35] E. Quinlan, A. López-Noriega, E. Thompson, H. M. Kelly, S. A. Cryan, F. J. O'Brien, Journal of Controlled Release 2015, 198, 71. 
[36] S. Sotome, T. Uemura, M. Kikuchi, J. Chen, S. Itoh, J. Tanaka, T. Tateishi, K. Shinomiya, Materials Science and Engineering: C 2004, 24, 341.

[37] Z. Ali, A. Islam, P. Sherrell, M. Le-Moine, G. Lolas, K. Syrigos, M. Rafat, L. D. Jensen, Biology Open 2018, 7, bio027060.

[38] B. M. Foidl, B. Ucar, A. Schwarz, A. L. Rebelo, A. Pandit, C. Humpel, Journal of Neuroscience Methods 2018, 295, 77.

[39] J. Venugopal, S. Low, A. T. Choon, T. S. Sampath Kumar, S. Ramakrishna, Journal of Materials Science: Materials in Medicine 2008, 19, 2039.

[40] Y. Kang, N. Mochizuki, A. Khademhosseini, J. Fukuda, Y. Yang, Acta Biomaterialia 2015, 11, 449.

[41] T. Kawai, K. Matsui, Y. Ezoe, F. Kajii, O. Suzuki, T. Takahashi, S. Kamakura, Materials 2018, 11, 229.

[42] L. Chen, J. Hu, J. Ran, X. Shen, H. Tong, International Journal of Biological Macromolecules 2014, 65, 1.

[43] L. Cen, W. Liu, L. Cui, W. Zhang, Y. Cao, Pediatric Research 2008, 63, 492.

[44] J. Chen, Q. Li, J. Xu, Y. Huang, Y. Ding, H. Deng, S. Zhao, R. Chen, Artificial Organs 2005, 29, 104.

[45] Y. Liu, L. Ren, K. Long, L. Wang, Y. Wang, Acta Biomaterialia 2014, 10, 289.

[46] S. Rhee, J. L. Puetzer, B. N. Mason, C. A. Reinhart-King, L. J. Bonassar, ACS Biomaterials Science \& Engineering 2016, 2, 1800.

[47] M. C. Gómez-Guillén, B. Giménez, M. E. López-Caballero, M. P. Montero, Food Hydrocolloids 2011, $25,1813$.

[48] L. Guo, R. H. Colby, C. P. Lusignan, A. M. Howe, Macromolecules 2003, 36, 10009.

[49] Z. Wang, S. Xu, Critical Reviews in Food Science and Nutrition 2001, 41, 481.

[50] S. Farris, J. Song, Q. Huang, Journal of Agricultural and Food Chemistry 2010, 58, 998.

[51] V. K. Selestina Gorgieva.

[52] P. V. Kozlov, G. I. Burdygina, Polymer 1983, 24, 651.

[53] A. George, G. Radhakrishnan, K. T. Joseph, Die Angewandte Makromolekulare Chemie 1985, 131, 169.

[54] J. Stejskal, D. Straková, P. Kratochvíl, Journal of Applied Polymer Science 1988, 36, 215.

[55] M. Sadeghi, B. Heidari, Materials 2011, 4, 543.

[56] K. D. Gill, I. K. Mehta, B. N. Misra, Journal of Macromolecular Science: Part A - Chemistry 1982, 18, 445.

[57] G. A. Radhakrishnan, K. T. Joseph, Journal of Macromolecular Science: Part A - Chemistry 1984, 21, 179.

[58] W.-T. Kuo, H.-Y. Huang, M.-J. Chou, M.-C. Wu, Y.-Y. Huang, Journal of Nanomaterials 2011, 2011.

[59] D. Kołbuk, Journal of Biomaterials Science, Polymer Edition 2014, 25, 2009.

[60] Y. Wang, M. Ma, J. Wang, W. Zhang, W. Lu, Y. Gao, B. Zhang, Y. Guo, Materials 2018, 11, 1345.

[61] G. Irmak, T. T. Demirtaş, M. Gümüşderelioğlu, ACS Biomaterials Science \& Engineering 2018.

[62] K. A. DiVito, M. A. Daniele, S. A. Roberts, F. S. Ligler, A. A. Adams, Biomaterials 2017, 138, 142.

[63] S. Nagarajan, L. Soussan, M. Bechelany, C. Teyssier, V. Cavaillès, C. Pochat-Bohatier, P. Miele, N.

Kalkura, J.-M. Janot, S. Balme, Journal of Materials Chemistry B 2016, 4, 1134.

[64] H. R. Bakhsheshi-Rad, Z. Hadisi, E. Hamzah, A. F. Ismail, M. Aziz, M. Kashefian, Materials Letters 2017, 207, 179.

[65] S. Nagarajan, H. Belaid, C. Pochat-Bohatier, C. Teyssier, I. latsunskyi, E. Coy, S. Balme, D. Cornu, P. Miele, N. S. Kalkura, V. Cavaillès, M. Bechelany, ACS Applied Materials \& Interfaces 2017, 9, 33695.

[66] S. Nagarajan, C. Pochat-Bohatier, C. Teyssier, S. Balme, P. Miele, N. Kalkura, V. Cavaillès, M. Bechelany, RSC Advances 2016, 6, 109150.

[67] B. Wang, W. Yang, J. McKittrick, M. A. Meyers, Progress in Materials Science 2016, 76, 229.

[68] A. Shavandi, T. H. Silva, A. A. Bekhit, A. E.-D. A. Bekhit, Biomaterials Science 2017, 5, 1699.

[69] J. McKittrick, P.-Y. Chen, S. G. Bodde, W. Yang, E. E. Novitskaya, M. A. Meyers, JOM 2012, 64, 449. 
[70] P. Sierpinski, J. Garrett, J. Ma, P. Apel, D. Klorig, T. Smith, L. A. Koman, A. Atala, M. Van Dyke, Biomaterials 2008, 29, 118.

[71] K. Song, H. Xu, K. Xie, Y. Yang, ACS Sustainable Chemistry \& Engineering 2017, 5, 5669.

[72] R. Nakata, Y. Osumi, S. Miyagawa, A. Tachibana, T. Tanabe, Journal of Bioscience and Bioengineering 2015, 120, 111.

[73] D. Yu, J. Y. Cai, J. S. Church, L. Wang, ACS Applied Materials \& Interfaces 2014, 6, 1236.

[74] J. Schaller, T. Miyamoto, K. Shimamura, H. Inagaki, Journal of Applied Polymer Science 1980, 25, 783.

[75] M. Borrelli, N. Joepen, S. Reichl, D. Finis, M. Schoppe, G. Geerling, S. Schrader, Biomaterials 2015, 42, 112.

[76] X. Yang, H. Zhang, X. Yuan, S. Cui, Journal of Colloid and Interface Science 2009, 336, 756.

[77] E. Turner, L. Burnett, S. K. Yazdani, "Keratose as a Novel Drug Carrier for Drug Coated Balloons", in 2016 32nd Southern Biomedical Engineering Conference (SBEC), 201671.

[78] T. Posati, D. Giuri, M. Nocchetti, A. Sagnella, M. Gariboldi, C. Ferroni, G. Sotgiu, G. Varchi, R. Zamboni, A. Aluigi, European Polymer Journal 2018, 105, 177.

[79] S. Hamasaki, A. Tachibana, D. Tada, K. Yamauchi, T. Tanabe, Materials Science and Engineering: $C$ 2008, 28, 1250.

[80] S. Balaji, R. Kumar, R. Sripriya, P. Kakkar, D. V. Ramesh, P. N. K. Reddy, P. K. Sehgal, Materials Science and Engineering: C 2012, 32, 975.

[81] T. Tanabe, N. Okitsu, A. Tachibana, K. Yamauchi, Biomaterials 2002, 23, 817.

[82] P. J. Apel, J. P. Garrett, P. Sierpinski, J. Ma, A. Atala, T. L. Smith, L. A. Koman, M. E. Van Dyke, The Journal of Hand Surgery 2008, 33, 1541.

[83] M. Park, H. K. Shin, B.-S. Kim, M. J. Kim, I.-S. Kim, B.-Y. Park, H.-Y. Kim, Materials Science and Engineering: C 2015, 55, 88.

[84] J. K. Placone, J. Navarro, G. W. Laslo, M. J. Lerman, A. R. Gabard, G. J. Herendeen, E. E. Falco, S. Tomblyn, L. Burnett, J. P. Fisher, Annals of Biomedical Engineering 2017, 45, 237.

[85] O. Hakimi, D. P. Knight, F. Vollrath, P. Vadgama, Composites Part B: Engineering 2007, 38, 324.

[86] T. Scheibel, Prion 2008, 2, 154.

[87] M. Andersson, L. Holm, Y. Ridderstråle, J. Johansson, A. Rising, Biomacromolecules 2013, 14, 2945.

[88] J. E. Garb, N. A. Ayoub, C. Y. Hayashi, BMC Evolutionary Biology 2010, 10, 243.

[89] J. M. Gosline, P. A. Guerette, C. S. Ortlepp, K. N. Savage, Journal of Experimental Biology 1999, 202, 3295.

[90] S. A. C. Gould, K. T. Tran, J. C. Spagna, A. M. F. Moore, J. B. Shulman, International Journal of Biological Macromolecules 1999, 24, 151.

[91] R. Fedič, M. Žurovec, F. Sehnal, Journal of Biological Chemistry 2003, 278, 35255.

[92] F. Han, S. Liu, X. Liu, Y. Pei, S. Bai, H. Zhao, Q. Lu, F. Ma, D. L. Kaplan, H. Zhu, Acta Biomaterialia 2014, 10, 921.

[93] K. Numata, P. Cebe, D. L. Kaplan, Biomaterials 2010, 31, 2926.

[94] M. K. DeBari, R. D. Abbott, Wiley Interdisciplinary Reviews: Nanomedicine and Nanobiotechnology, 0, e1534.

[95] M. N. Keyser, M. A. Bai, R. D. Abbott, Connective Tissue Research 2018, 1.

[96] H. J. Kim, M. K. Kim, K. H. Lee, S. K. Nho, M. S. Han, I. C. Um, International Journal of Biological Macromolecules 2017, 104, 294.

[97] S. Keten, Z. Xu, B. Ihle, M. J. Buehler, Nature Materials 2010, 9, 359.

[98] M. R. Sommer, M. Schaffner, D. Carnelli, A. R. Studart, ACS Applied Materials \& Interfaces 2016, 8, 34677.

[99] S. H. Kim, Y. S. Nam, T. S. Lee, W. H. Park, Polymer Journal 2003, 35, 185.

[100] L. Xiao, G. Lu, Q. Lu, D. L. Kaplan, ACS Biomaterials Science \& Engineering 2016, 2, 2050. 
[101] E. Wenk, A. J. Wandrey, H. P. Merkle, L. Meinel, Journal of Controlled Release 2008, 132, 26. [102] F. Mottaghitalab, M. Farokhi, M. A. Shokrgozar, F. Atyabi, H. Hosseinkhani, Journal of Controlled Release 2015, 206, 161.

[103] L. Lamboni, M. Gauthier, G. Yang, Q. Wang, Biotechnology Advances 2015, 33, 1855.

[104] B. Kundu, R. Rajkhowa, S. C. Kundu, X. Wang, Advanced Drug Delivery Reviews 2013, 65, 457.

[105] M. Auger, International Materials Reviews 2016, 61, 127.

[106] T. Yucel, M. L. Lovett, D. L. Kaplan, Journal of Controlled Release 2014, 190, 381.

[107] Y. Wang, D. J. Blasioli, H.-J. Kim, H. S. Kim, D. L. Kaplan, Biomaterials 2006, 27, 4434.

[108] S. Bhumiratana, W. L. Grayson, A. Castaneda, D. N. Rockwood, E. S. Gil, D. L. Kaplan, G. VunjakNovakovic, Biomaterials 2011, 32, 2812.

[109] Q. Wang, G. Han, S. Yan, Q. Zhang, Materials 2019, 12, 504.

[110] S. H. Kim, Y. K. Yeon, J. M. Lee, J. R. Chao, Y. J. Lee, Y. B. Seo, M. T. Sultan, O. J. Lee, J. S. Lee, S.-i. Yoon, I.-S. Hong, G. Khang, S. J. Lee, J. J. Yoo, C. H. Park, Nature Communications 2018, 9, 1620.

[111] S. Das, F. Pati, Y.-J. Choi, G. Rijal, J.-H. Shim, S. W. Kim, A. R. Ray, D.-W. Cho, S. Ghosh, Acta Biomaterialia 2015, 11, 233.

[112] S. M. Mithieux, S. G. Wise, A. S. Weiss, Advanced Drug Delivery Reviews 2013, 65, 421.

[113] J. Rosenbloom, W. R. Abrams, R. Mecham, The FASEB Journal 1993, 7, 1208.

[114] P. Chrzanowski, S. Keller, J. Cerreta, I. Mandl, G. M. Turino, The American Journal of Medicine

1980, 69, 351.

[115] S. Ayad, R. Boot-Handford, M. J. Humphries, K. E. Kadler, A. Shuttleworth, "2 - Extracellular matrices", in The Extracellular Matrix FactsBook (Second Edition), S. Ayad, R. Boot-Handford, M.J. Humphries, K.E. Kadler, and A. Shuttleworth, Eds., Academic Press, San Diego, 1998, p. 11.

[116] B. Starcher, R. L. Aycock, C. H. Hill, Journal of Histochemistry \& Cytochemistry 2005, 53, 431.

[117] S. Sandefur, R. A. Pierce, Experimental Lung Research 1997, 23, 131.

[118] S. K. Karnik, B. S. Brooke, A. Bayes-Genis, L. Sorensen, J. D. Wythe, R. S. Schwartz, M. T. Keating, D. Y. Li, Development 2003, 130, 411.

[119] N. Fujimoto, S. Tajima, A. Ishibashi, Journal of Investigative Dermatology 2000, 115, 633.

[120] E. Jin, P. T. Lee, W. B. Jeon, W.-J. Li, Regenerative Engineering and Translational Medicine 2016, 2, 85.

[121] S. G. Wise, G. C. Yeo, M. A. Hiob, J. Rnjak-Kovacina, D. L. Kaplan, M. K. C. Ng, A. S. Weiss, Acta Biomaterialia 2014, 10, 1532.

[122] P. Kuppan, S. Sethuraman, U. M. Krishnan, Journal of Biomedical Materials Research Part A 2015, 103, 2236.

[123] S. M. Mithieux, A. S. Weiss, "Elastin", in Advances in Protein Chemistry, Academic Press, 2005, p. 437.

[124] V. A. Kumar, J. M. Caves, C. A. Haller, E. Dai, L. Liu, S. Grainger, E. L. Chaikof, Acta Biomaterialia 2013, 9, 8067.

[125] M. J. McClure, S. A. Sell, D. G. Simpson, B. H. Walpoth, G. L. Bowlin, Acta Biomaterialia 2010, 6, 2422.

[126] J. Gao, P. Crapo, R. Nerem, Y. Wang, Journal of Biomedical Materials Research Part A 2008, 85A, 1120.

[127] A. V. Janorkar, P. Rajagopalan, M. L. Yarmush, Z. Megeed, Biomaterials 2008, 29, 625.

[128] E. N. Lamme, H. J. de Vries, H. van Veen, G. Gabbiani, W. Westerhof, E. Middelkoop, Journal of Histochemistry \& Cytochemistry 1996, 44, 1311.

[129] B. K. H. L. Boekema, M. Vlig, L. Olde Damink, E. Middelkoop, L. Eummelen, A. V. Bühren, M. M. W. Ulrich, Journal of Materials Science: Materials in Medicine 2014, 25, 423.

[130] U. Wollina, Journal of Cutaneous and Aesthetic Surgery 2011, 4, 176. 
[131] J. Rnjak-Kovacina, S. G. Wise, Z. Li, P. K. M. Maitz, C. J. Young, Y. Wang, A. S. Weiss, Acta Biomaterialia 2012, 8, 3714.

[132] L. Buttafoco, P. Engbers-Buijtenhuijs, A. A. Poot, P. J. Dijkstra, W. F. Daamen, T. H. van Kuppevelt, I. Vermes, J. Feijen, Journal of Biomedical Materials Research Part B: Applied Biomaterials 2006, 77B, 357. [133] N. Annabi, A. Fathi, S. M. Mithieux, P. Martens, A. S. Weiss, F. Dehghani, Biomaterials 2011, 32, 1517.

[134] K. E. Swindle-Reilly, C. S. Paranjape, C. A. Miller, Progress in Biomaterials 2014, 3, 20.

[135] M. Hans, E. Burt, K. Robert, Advances in Wound Care 2014, 3, 367.

[136] V. Thomas, X. Zhang, S. A. Catledge, Y. K. Vohra, Biomedical Materials 2007, 2, 224.

[137] W. F. Daamen, P. J. Geutjes, H. T. B. van Moerkerk, S. T. M. Nillesen, R. G. Wismans, T. Hafmans, L. P. W. J. van den Heuvel, A. M. A. Pistorius, J. H. Veerkamp, J. C. M. van Hest, T. H. van Kuppevelt, Advanced Materials 2007, 19, 673.

[138] A. Bandiera, A. Markulin, L. Corich, F. Vita, V. Borelli, Biomacromolecules 2014, 15, 416.

[139] A. Bandiera, S. Passamonti, L. S. Dolci, M. L. Focarete, Frontiers in Bioengineering and Biotechnology 2018, 6.

[140] J. W. Weisel, Biophysical Chemistry 2004, 112, 267.

[141] J. W. Weisel, "Fibrinogen and Fibrin", in Advances in Protein Chemistry, Academic Press, 2005, p. 247.

[142] J. W. Weisel, R. I. Litvinov, Blood 2013, 121, 1712.

[143] L. A. Reis, L. L. Y. Chiu, N. Feric, L. Fu, M. Radisic, Journal of Tissue Engineering and Regenerative Medicine 2016, 10, 11.

[144] M. O. Chrobak, K. J. Hansen, J. R. Gershlak, M. Vratsanos, M. Kanellias, G. R. Gaudette, G. D. Pins, ACS Biomaterials Science \& Engineering 2017, 3, 1394.

[145] C. H. Park, J.-H. Oh, H.-M. Jung, Y. Choi, S. U. Rahman, S. Kim, T.-I. Kim, H.-I. Shin, Y.-S. Lee, F. H. Yu, J.-H. Baek, H.-M. Ryoo, K. M. Woo, Acta Biomaterialia 2017, 61, 134.

[146] R. Arun Kumar, A. Sivashanmugam, S. Deepthi, J. D. Bumgardner, S. V. Nair, R. Jayakumar, Carbohydrate Polymers 2016, 140, 144.

[147] E. Sproul, S. Nandi, A. Brown, "6 - Fibrin biomaterials for tissue regeneration and repair", in Peptides and Proteins as Biomaterials for Tissue Regeneration and Repair, M.A. Barbosa and M.C.L. Martins, Eds., Woodhead Publishing, 2018, p. 151.

[148] A. Takei, Y. Tashiro, Y. Nakashima, K. Sueishi, In Vitro Cellular \& Developmental Biology - Animal $1995,31,467$.

[149] N. F. Huang, A. Lam, Q. Fang, R. E. Sievers, S. Li, R. J. Lee, Regenerative Medicine 2009, 4, 527. [150] G. Zhang, X. Wang, Z. Wang, J. Zhang, A. P. L. Suggs, Tissue Engineering 2006, 12, 9.

[151] I. Catelas, N. Sese, B. M. Wu, J. C. Y. Dunn, S. Helgerson, B. Tawil, Tissue Engineering 2006, 12, 2385.

[152] M. M. Martino, M. Mochizuki, D. A. Rothenfluh, S. A. Rempel, J. A. Hubbell, T. H. Barker, Biomaterials 2009, 30, 1089.

[153] J. W. Gibble, P. M. Ness, Transfusion 1990, 30, 741.

[154] A. Mohandas, B. S. Anisha, K. P. Chennazhi, R. Jayakumar, Colloids and Surfaces B: Biointerfaces 2015, 127, 105.

[155] E. Briganti, D. Spiller, C. Mirtelli, S. Kull, C. Counoupas, P. Losi, S. Senesi, R. Di Stefano, G. Soldani, Journal of Controlled Release 2010, 142, 14.

[156] S.-J. Kim, J.-D. Jang, S.-K. Lee, Cytotechnology 2007, 54, 115.

[157] C. Holt, J. A. Carver, H. Ecroyd, D. C. Thorn, Journal of Dairy Science 2013, 96, 6127.

[158] P. C. Pereira, Nutrition 2014, 30, 619.

[159] L. K. Creamer, A. K. H. MacGibbon, International Dairy Journal 1996, 6, 539.

[160] J.-L. Audic, B. Chaufer, G. Daufin, Lait 2003, 83, 417. 
[161] M. H. ABD EL-SALAM, S. EL-SHIBINY, International Journal of Dairy Technology 2012, 65, 13. [162] A. O. Elzoghby, W. S. Abo El-Fotoh, N. A. Elgindy, Journal of Controlled Release 2011, 153, 206.

[163] Y. D. Livney, Current Opinion in Colloid \& Interface Science 2010, 15, 73.

[164] H. M. Farrell, E. L. Malin, E. M. Brown, P. X. Qi, Current Opinion in Colloid \& Interface Science 2006, $11,135$.

[165] P. F. Fox, A. Brodkorb, International Dairy Journal 2008, 18, 677.

[166] A. Gonzalez-Jordan, P. Thomar, T. Nicolai, J. Dittmer, Food Hydrocolloids 2015, 51, 88.

[167] T. K. Głąb, J. Boratyński, Topics in Current Chemistry 2017, 375, 71.

[168] X. Zhen, X. Wang, C. Xie, W. Wu, X. Jiang, Biomaterials 2013, 34, 1372.

[169] S. Kumar, S. K. Singh, International Journal of Biological Macromolecules 2017, 96, 403.

[170] Y. Luo, K. Pan, Q. Zhong, International Journal of Pharmaceutics 2015, 486, 59.

[171] H. Chen, Y. Zhang, Q. Zhong, Journal of Food Engineering 2015, 144, 93.

[172] J. Huang, Q. Shu, L. Wang, H. Wu, A. Y. Wang, H. Mao, Biomaterials 2015, 39, 105.

[173] A. O. Elzoghby, B. Z. Vranic, W. M. Samy, N. A. Elgindy, International Journal of Pharmaceutics 2015, 491, 113.

[174] K. Marshall, Alternative medicinal review a journal of clinical therapeutics 2004, 9.

[175] S. M. Loveday, J. Su, M. A. Rao, S. G. Anema, H. Singh, International Dairy Journal 2012, 26, 133.

[176] L. G. Phillips, S. E. Hawks, J. B. German, Journal of Agricultural and Food Chemistry 1995, 43, 613.

[177] C. C. van den Akker, M. Schleeger, M. Bonn, G. H. Koenderink, "Chapter 31 - Structural Basis for the Polymorphism of $\beta$-Lactoglobulin Amyloid-Like Fibrils", in Bio-nanoimaging, V.N. Uversky and Y.L. Lyubchenko, Eds., Academic Press, Boston, 2014, p. 333.

[178] N. Giamblanco, D. Coglitore, A. Gubbiotti, T. Ma, E. Balanzat, J.-M. Janot, M. Chinappi, S. Balme, Analytical Chemistry 2018, 90, 12900.

[179] N. Giamblanco, D. Coglitore, J.-M. Janot, P. E. Coulon, B. Charlot, S. Balme, Sensors and Actuators B: Chemical 2018, 260, 736.

[180] A. Abaee, M. Mohammadian, S. M. Jafari, Trends in Food Science \& Technology 2017, 70, 69.

[181] C. Schmitt, C. Moitzi, C. Bovay, M. Rouvet, L. Bovetto, L. Donato, M. E. Leser, P. Schurtenberger, A. Stradner, Soft Matter 2010, 6, 4876.

[182] Y. Liu, D. Liu, G. Wei, Y. Ma, B. Bhandari, P. Zhou, Innovative Food Science \& Emerging

Technologies 2018, 49, 116.

[183] C. O. Ferreira, C. A. Nunes, I. Delgadillo, J. A. Lopes-da-Silva, Food Research International 2009, 42, 807.

[184] V. Gilbert, M. Rouabhia, H. Wang, A.-L. Arnould, G. Remondetto, M. Subirade, Biomaterials 2005, $26,7471$.

[185] Z. Shafaei, B. Ghalandari, A. Vaseghi, A. Divsalar, T. Haertlé, A. A. Saboury, L. Sawyer, Nanomedicine: Nanotechnology, Biology and Medicine 2017, 13, 1685.

[186] J. Colín-Orozco, M. Zapata-Torres, G. Rodríguez-Gattorno, R. Pedroza-Islas, Food Biophysics 2015, 10, 134.

[187] L. Chen, M. Subirade, Biomaterials 2006, 27, 4646.

[188] L. Chen, G. E. Remondetto, M. Subirade, Trends in Food Science \& Technology 2006, 17, 272.

[189] S. M. Ahmed, H. Ahmed, C. Tian, Q. Tu, Y. Guo, J. Wang, Colloids and Surfaces B: Biointerfaces 2016, 143, 371.

[190] T. J. Anderson, B. P. Lamsal, Cereal Chemistry 2011, 88, 159.

[191] R. Shukla, M. Cheryan, Industrial Crops and Products 2001, 13, 171.

[192] R. Paliwal, S. Palakurthi, Journal of Controlled Release 2014, 189, 108.

[193] F. F. O. Sousa, A. Luzardo-Álvarez, J. Blanco-Méndez, F. J. Otero-Espinar, M. Martín-Pastor, I. Sández Macho, European Journal of Pharmaceutics and Biopharmaceutics 2013, 85, 790. 
[194] Y. Zhang, L. Cui, X. Che, H. Zhang, N. Shi, C. Li, Y. Chen, W. Kong, Journal of Controlled Release 2015, 206, 206.

[195] L. Jing, X. Wang, H. Liu, Y. Lu, J. Bian, J. Sun, D. Huang, ACS Applied Materials \& Interfaces 2018, 10, 18551.

[196] C.-Y. Zhang, W. Zhang, L.-B. Mao, Y. Zhao, S.-H. Yu, CrystEngComm 2014, 16, 9513.

[197] Y. Zhang, L. Cui, F. Li, N. Shi, C. Li, X. Yu, Y. Chen, W. Kong, International Journal of Pharmaceutics

2016, 513, 191.

[198] G. W. Selling, Polymer Degradation and Stability 2010, 95, 2241.

[199] S. Wongsasulak, N. Puttipaiboon, T. Yoovidhya, Journal of Food Science 2013, 78, N926.

[200] P. Hurtado-López, S. Murdan, Journal of Drug Delivery Science and Technology 2005, 15, 267.

[201] X. Liu, Q. Sun, H. Wang, L. Zhang, J.-Y. Wang, Biomaterials 2005, 26, 109.

[202] J. Dong, Q. Sun, J.-Y. Wang, Biomaterials 2004, 25, 4691.

[203] S. Gong, H. Wang, Q. Sun, S.-T. Xue, J.-Y. Wang, Biomaterials 2006, 27, 3793.

[204] L. Chaunier, E. Leroy, G. D. Valle, M. Dalgalarrondo, B. Bakan, D. Marion, B. Madec, D. Lourdin, AIP Conference Proceedings 2017, 1914, 190003.

[205] H.-J. Wang, S.-J. Gong, Z.-X. Lin, J.-X. Fu, S.-T. Xue, J.-C. Huang, J.-Y. Wang, Biomaterials 2007, 28, 3952.

[206] H. Lian, X. Liu, Z. Meng, Journal of Materials Science 2019, 54, 719.

[207] L. Deng, Y. Li, F. Feng, H. Zhang, Food Hydrocolloids 2019, 87, 1.

[208] S. G. Giteru, M. A. Ali, I. Oey, Food Hydrocolloids 2019, 87, 270.

[209] R. Girija Aswathy, B. Sivakumar, D. Brahatheeswaran, T. Fukuda, Y. Yoshida, T. Maekawa, D. Sakthi Kumar, Advances in Natural Sciences: Nanoscience and Nanotechnology 2012, 3, 025006.

[210] S. Tansaz, A. R. Boccaccini, Journal of Biomedical Materials Research Part A 2016, 104, 553.

[211] E. G. Hammond, P. A. Murphy, L. A. Johnson, "SOY (SOYA) BEANS | Properties and Analysis", in Encyclopedia of Food Sciences and Nutrition (Second Edition), B. Caballero, Ed., Academic Press, Oxford, 2003, p. 5389.

[212] S. Iwabuchi, F. Yamauchi, Journal of Agricultural and Food Chemistry 1987, 35, 200.

[213] J. Guo, Y.-C. Jin, X.-Q. Yang, S.-J. Yu, S.-W. Yin, J.-R. Qi, Food Hydrocolloids 2013, 31, 220.

[214] K. Nishinari, Y. Fang, S. Guo, G. O. Phillips, Food Hydrocolloids 2014, 39, 301.

[215] N. Chen, L. Lin, W. Sun, M. Zhao, Journal of Agricultural and Food Chemistry 2014, 62, 9553.

[216] J. Guo, X.-Q. Yang, X.-T. He, N.-N. Wu, J.-M. Wang, W. Gu, Y.-Y. Zhang, Journal of Agricultural and Food Chemistry 2012, 60, 3782.

[217] R. Caillard, G. E. Remondetto, M. Subirade, Food Hydrocolloids 2010, $24,81$.

[218] Z. Zhong, X. S. Sun, Polymer 2001, 42, 6961.

[219] P. Guerrero, P. M. Stefani, R. A. Ruseckaite, K. de la Caba, Journal of Food Engineering 2011, 105, 65.

[220] R. Silva, B. Bulut, J. A. Roether, J. Kaschta, D. W. Schubert, A. R. Boccaccini, Journal of Molecular Structure 2014, 1073, 87.

[221] K. B. Chien, B. A. Aguado, P. J. Bryce, R. N. Shah, Acta Biomaterialia 2013, 9, 8983.

[222] K. B. Chien, R. N. Shah, Acta Biomaterialia 2012, 8, 694.

[223] Y.-e. Har-el, J. A. Gerstenhaber, R. Brodsky, R. B. Huneke, P. I. Lelkes, Wound Medicine 2014, 5, 9.

[224] A. Maltais, G. E. Remondetto, M. Subirade, Food Hydrocolloids 2010, $24,518$.

[225] S. Y. Cho, C. Rhee, LWT - Food Science and Technology 2002, 35, 151.

[226] S. Kokoszka, F. Debeaufort, A. Hambleton, A. Lenart, A. Voilley, Innovative Food Science \& Emerging Technologies 2010, 11, 503.

[227] K. B. Chien, E. Makridakis, R. N. Shah, Tissue Engineering Part C: Methods 2013, 19, 417.

[228] H.-H. Lin, F.-Y. Hsieh, C.-S. Tseng, S.-h. Hsu, Journal of Materials Chemistry B 2016, 4, 6694. 
